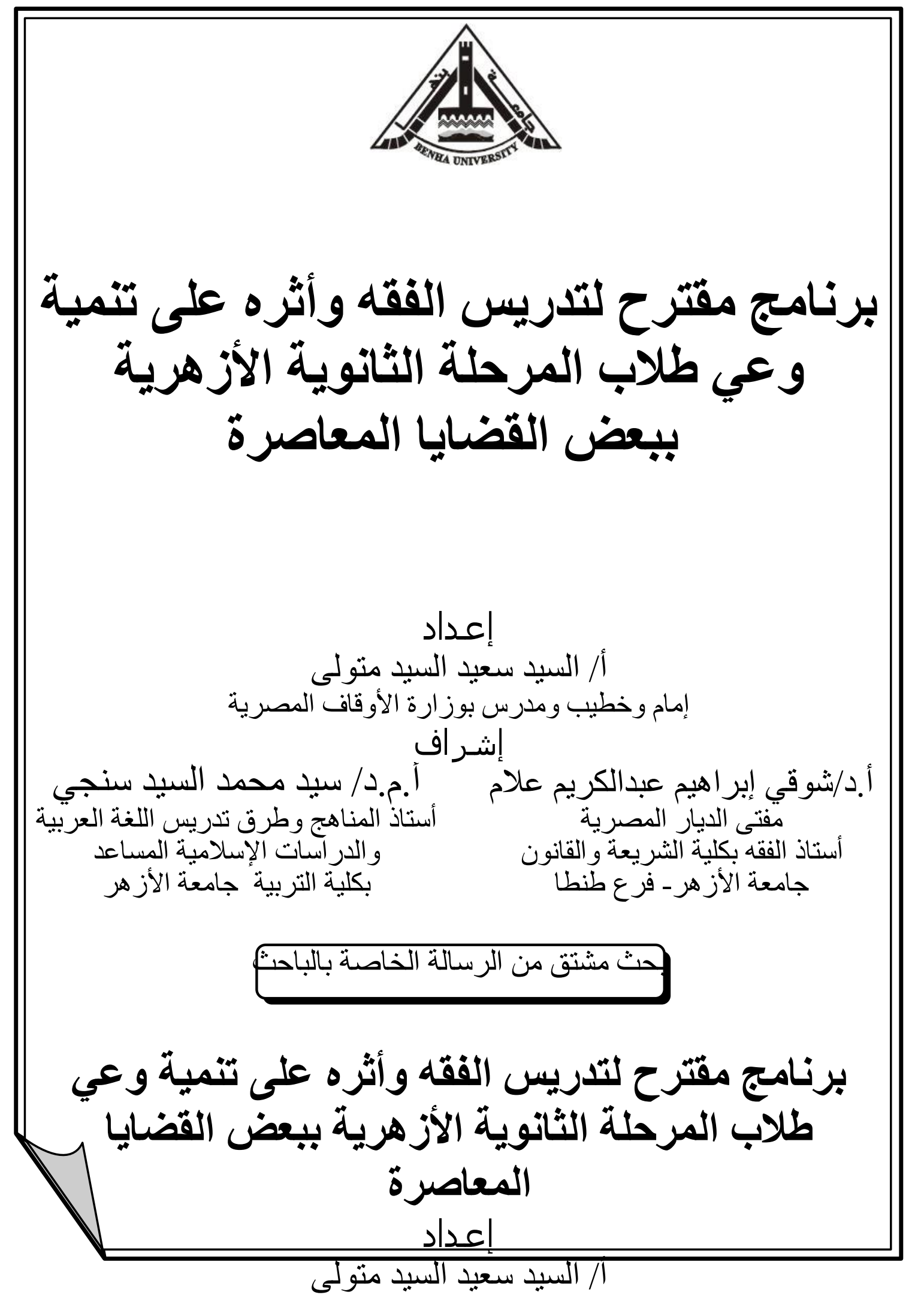


إمام وخطيب ومدرس بوزارة الأوقاف المصرية

أ.م.د/ سيد محمد السيد سنجي أستاذ المناهج وطرق تدريس الإئة اللغة العربية

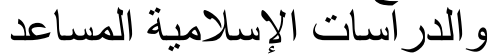
بكلية التربية جامعة الأز هر

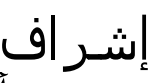

\section{مستخلـــص الدراســــة}

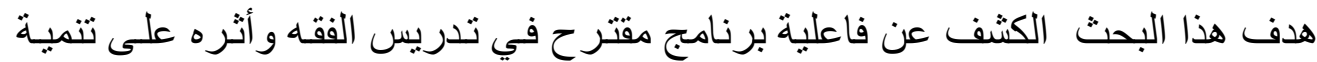

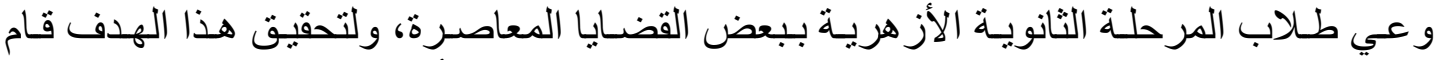

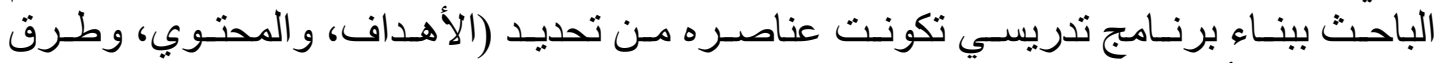

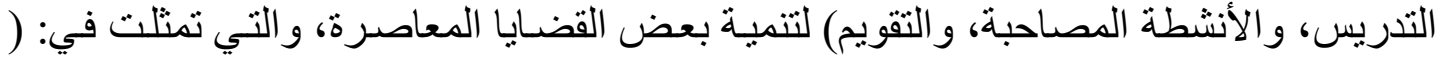

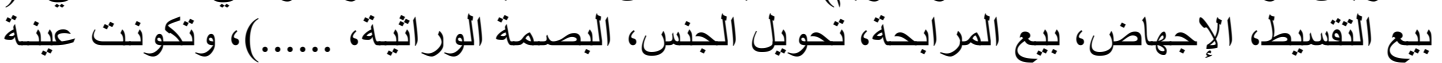

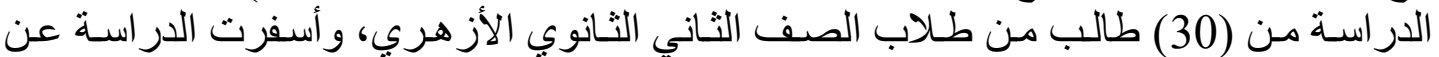
فاعلية البرنامج المقترح في تدريس الفقه و أثره على تنمية و وعي الطلاب عينة الدر اسلة. 
برنامج مقتر حلتنريس الققه و أثره على تتمية وعي طلاب

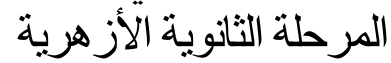

1 1 المقدمة و الإحساس بالمشكلة:

الإسلام دين عالمي أنزله الله إلى الناس كافة ينظم عقيدتهم و وعباداتهم ومعاملاتهم وسائر

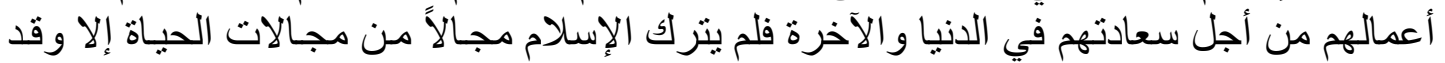

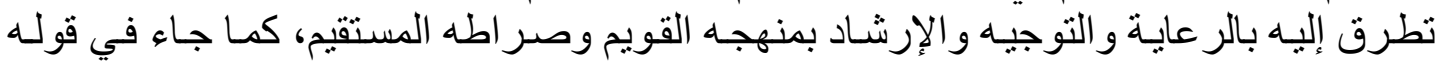

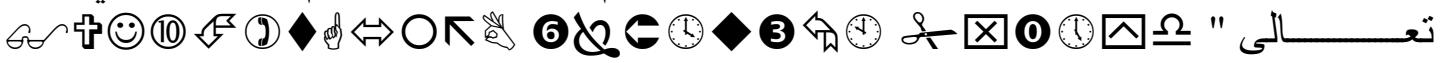
勇名口 $\rightarrow$ Q Q

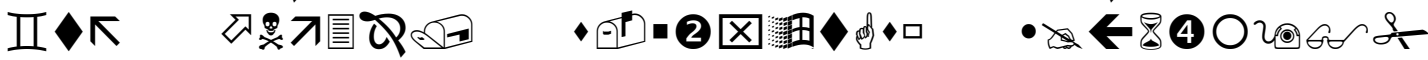

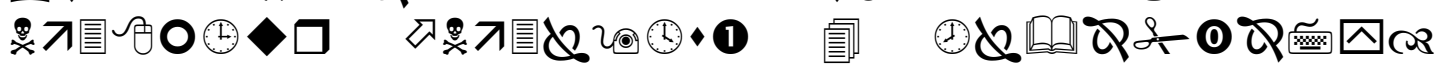

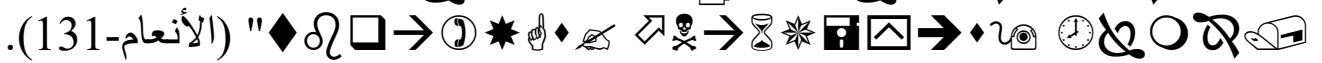

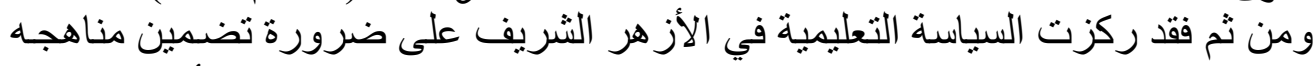

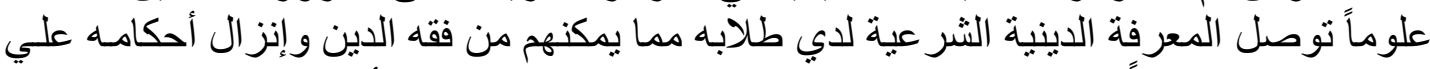

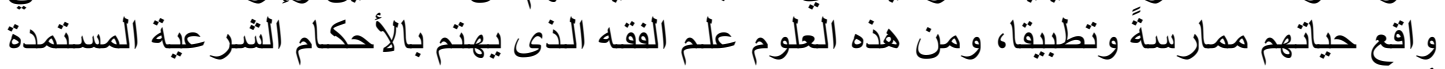
أدلتها التفصيلية من الكتاب و السنة.

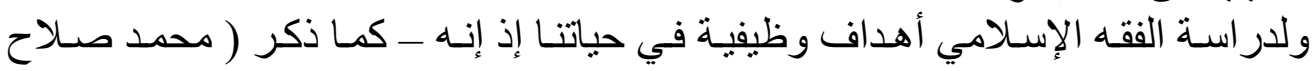

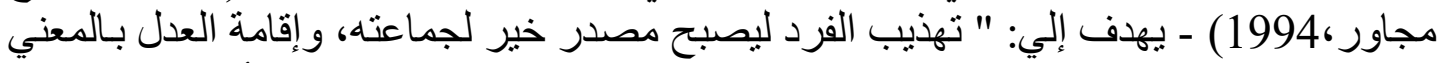

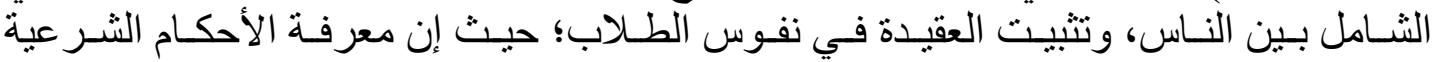

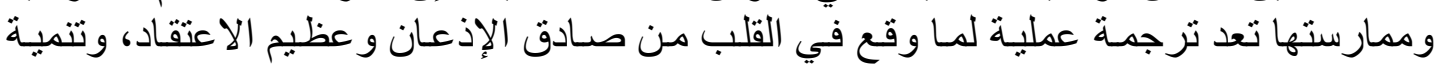

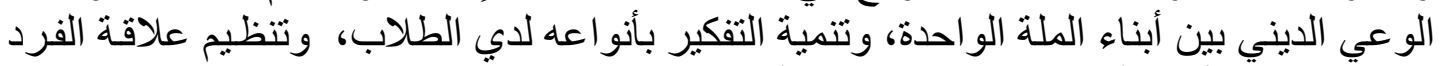
بربه و علاقته بأفر اد أسرته و علاقتته بالناس أجمعين".

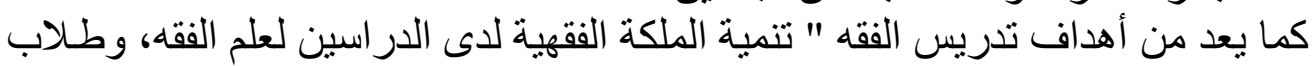

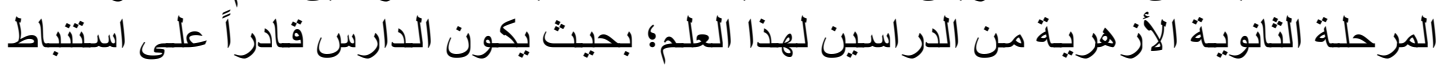

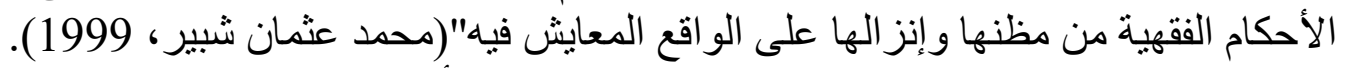

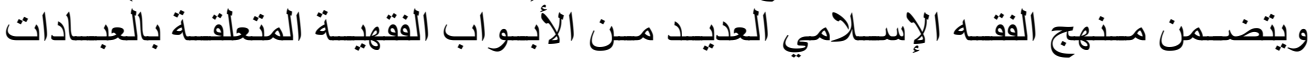

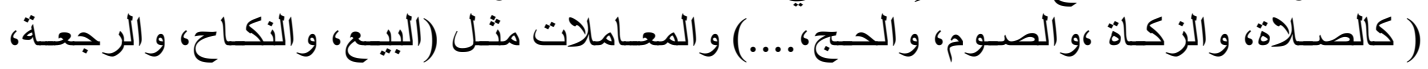

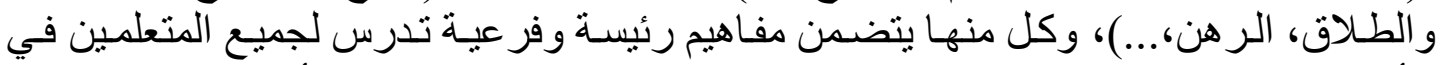

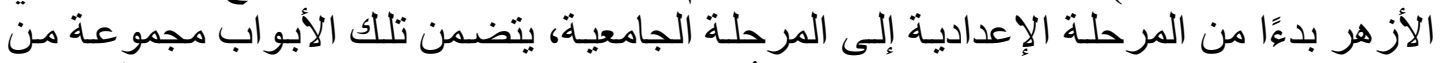

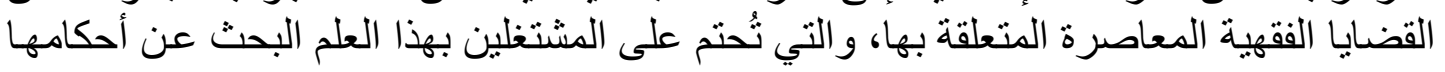

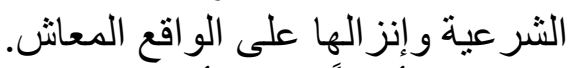

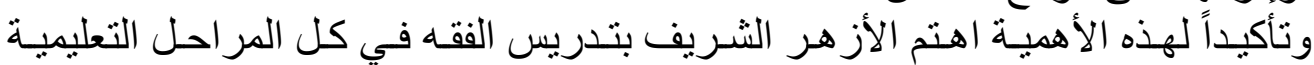

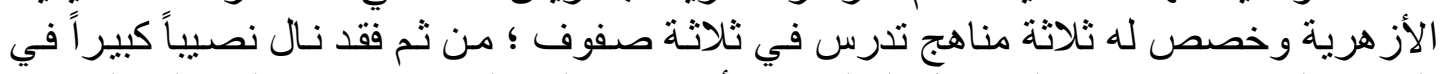

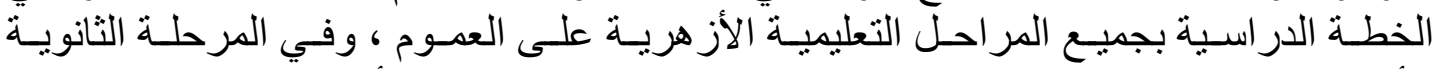

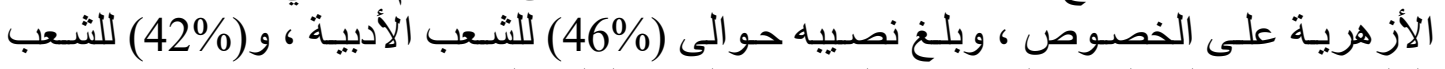

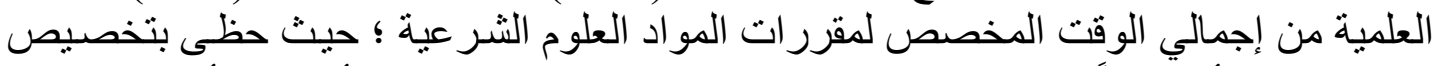

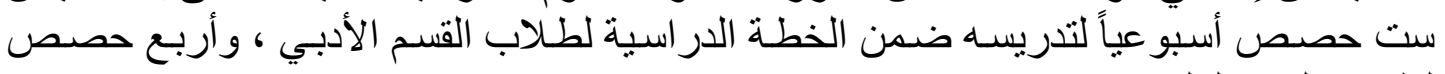

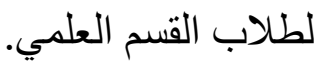

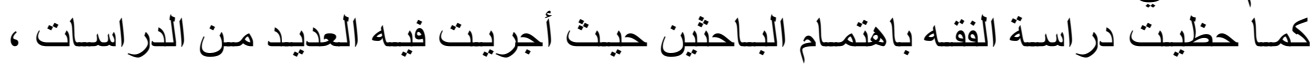

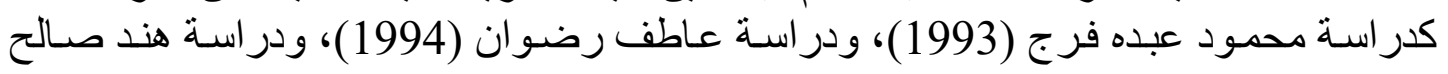




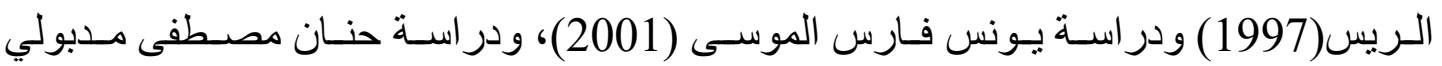

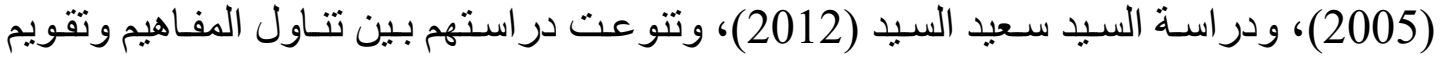

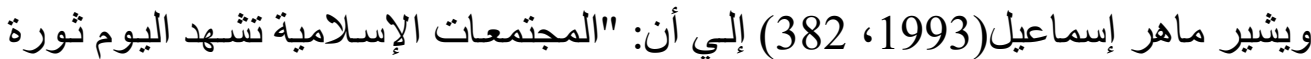

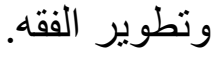

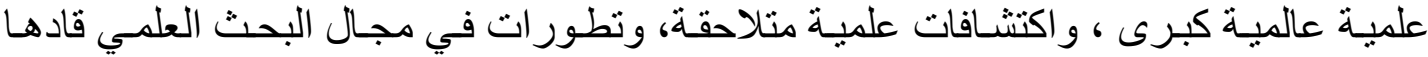

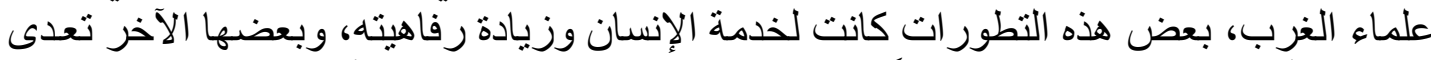

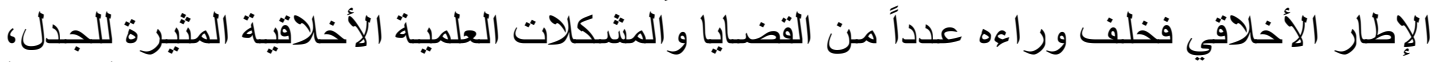

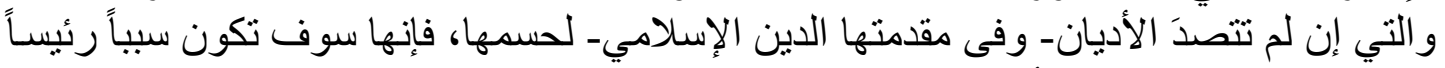
في تدمير الإنسان و انهيار أخلاقياته".

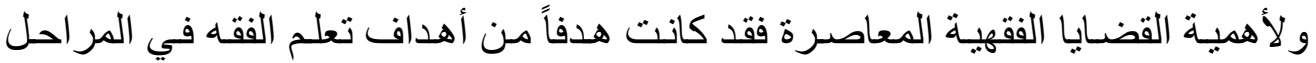

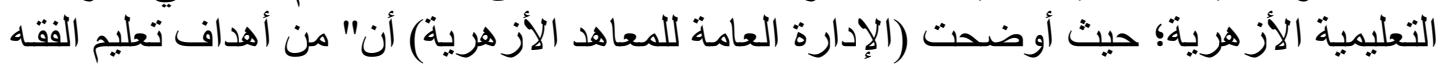

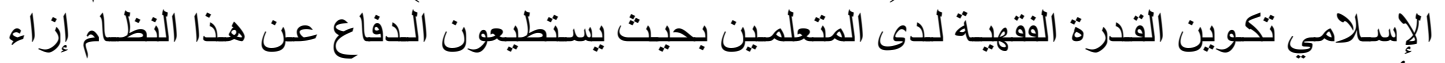

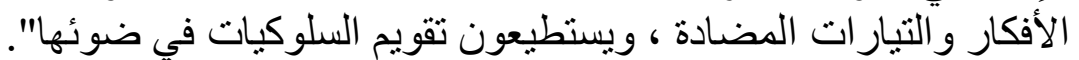

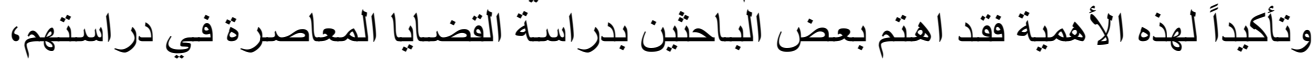

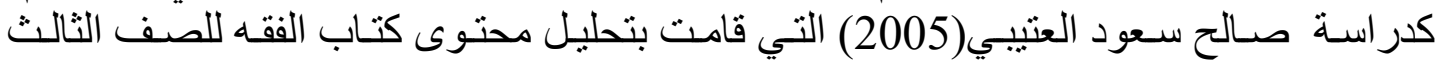

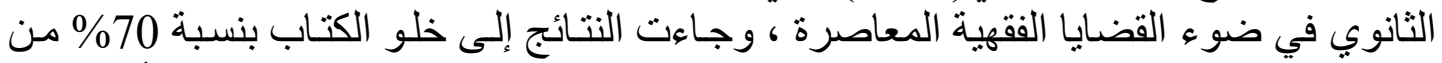

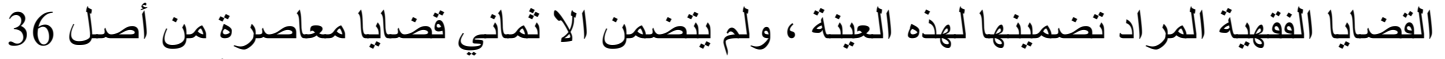

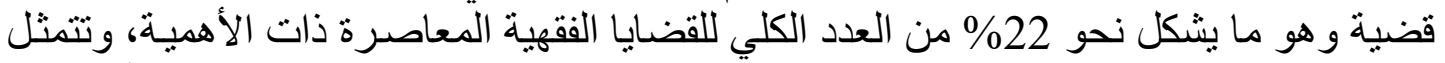

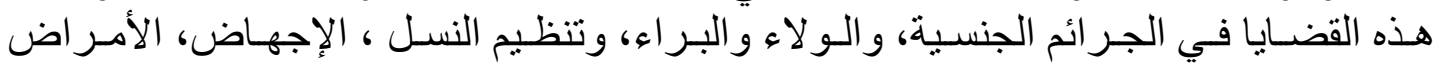
الجنسية، وتعاطي الدخدرات، الجهاد، العنصرية.

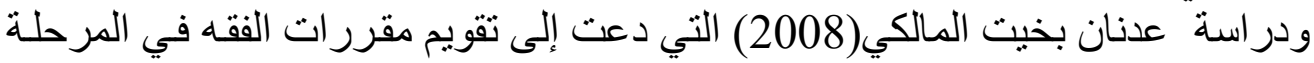

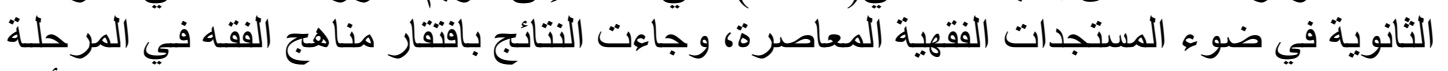

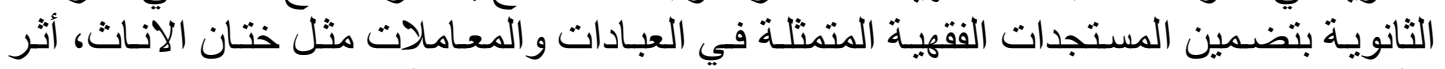

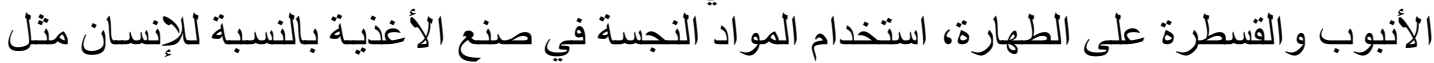

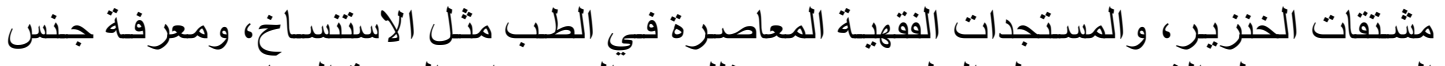

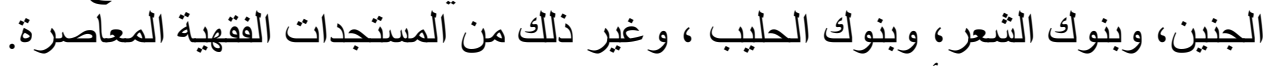

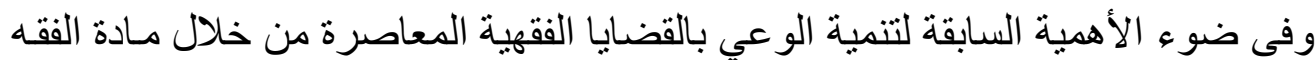

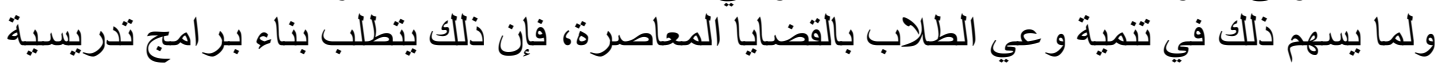

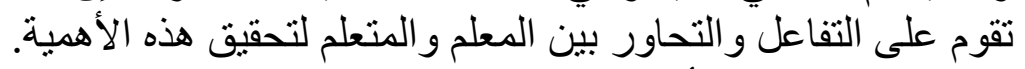

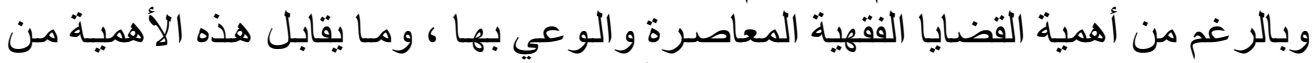

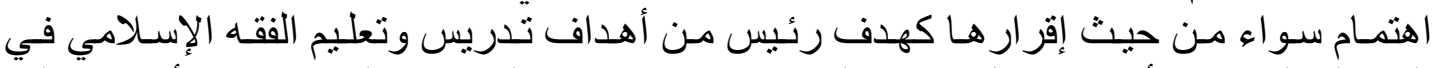

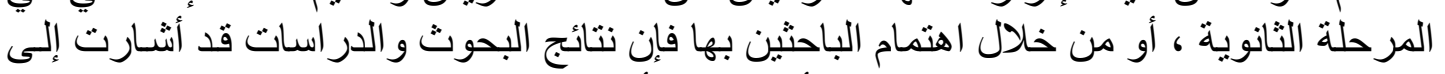

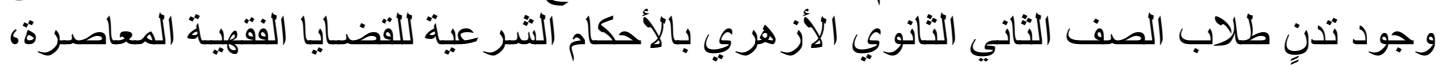

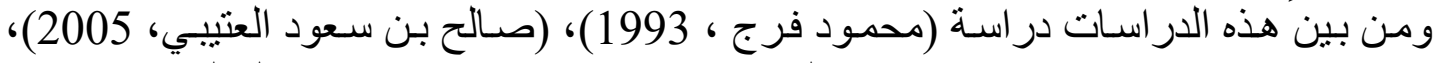

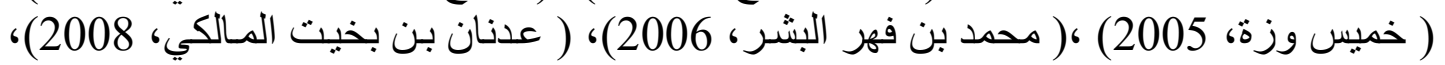

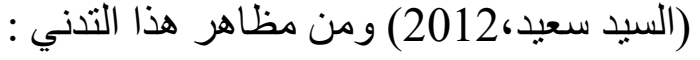

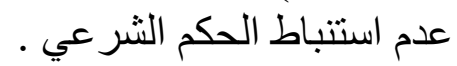
ق قلة المقارنة و إدر الك العلاقات بين موضو عات الفقه . 
برنامج مقتر حلتنريس الققه و أثره على تتمية وعي طلاب

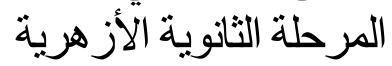

عدم تمكينهم من مهارة القياس.

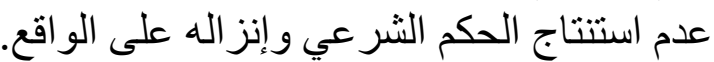
عدم معرفة الحكم الثرعي المتعلق بالقضايا الفقهية المعاصرة.

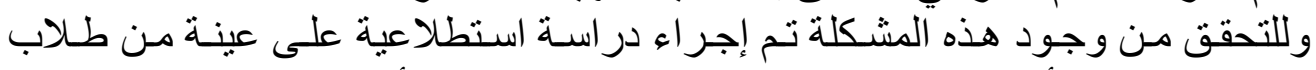

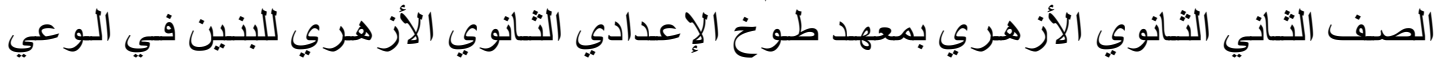

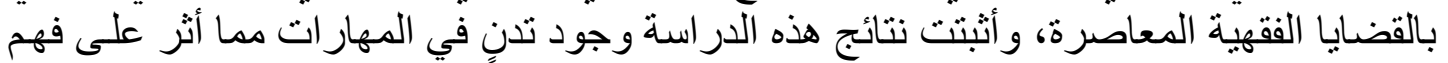
القضايا الفقهية المعاصرة، ومن ثم تولد الإحساس بمشكلة الدر اسةٍ الحالية لدى الباحثة

2- 2 تحـديـد المشكلــة تتحدد مشكلة الدر اسة الحالية في وجود تدنٍ في مستوى طلاب الصاب الصف الثناني الثانوي

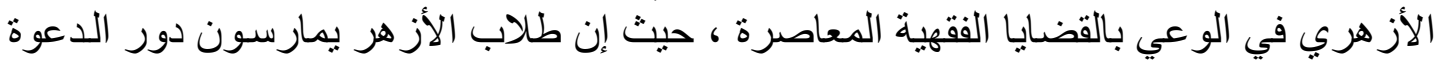

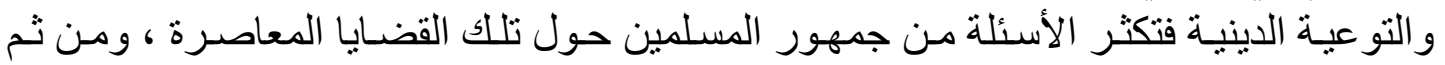

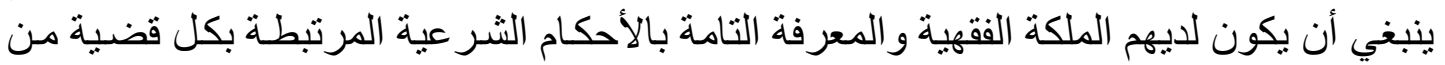

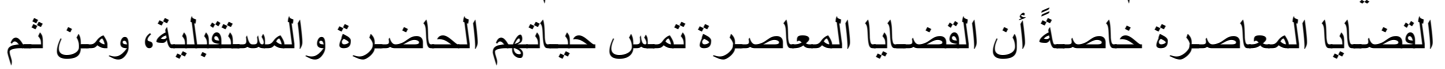

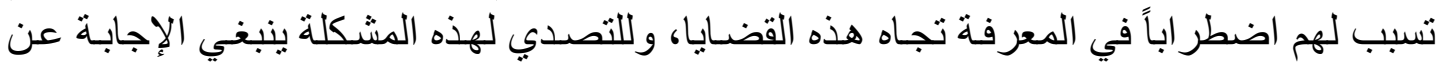

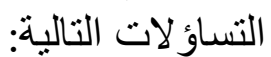

1- ما القضايا الفقهية المعاصرة اللازمة لطلاب الصف الثاني الثانوي الأزهري؟

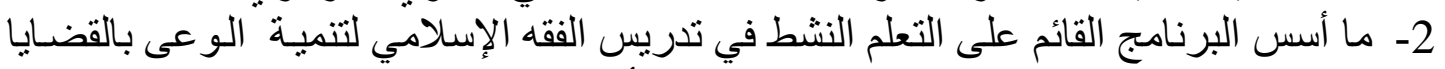

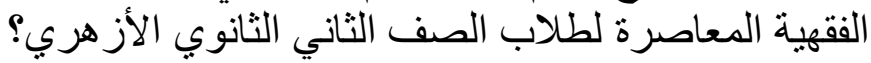

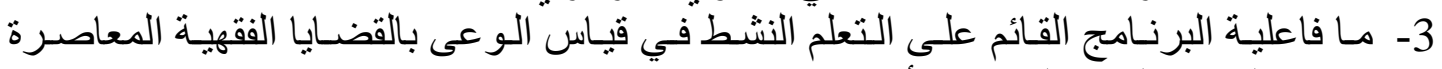
طلاب الصف الثاني الثانوي الأزهري؟

$$
\begin{aligned}
& \text { 3. } 3 \\
& \text { تقتصر الدراسة الحالية على الحدود الآتية: }
\end{aligned}
$$

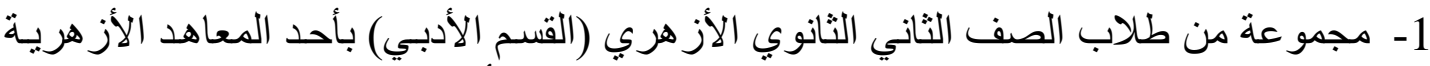

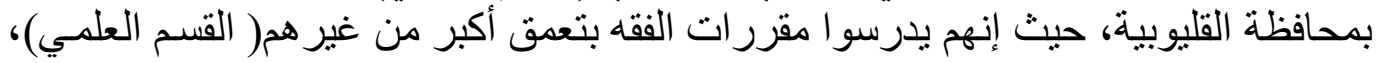

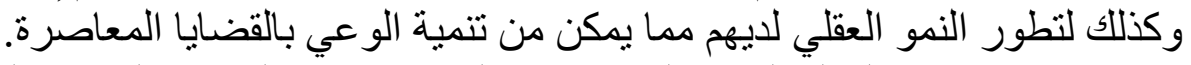

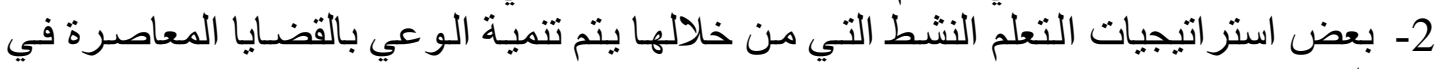
الفقه الإسلامي.

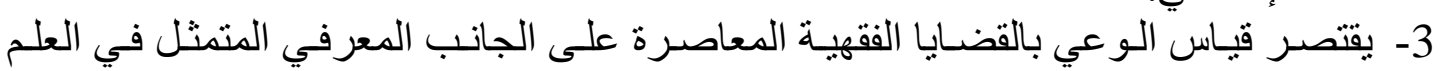
بالحكم الثر عي لكل قضية أو حادثة و استخر اج الأدلة الثر عية من مصادر ها.

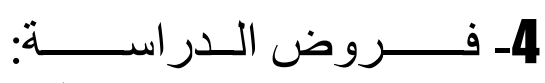

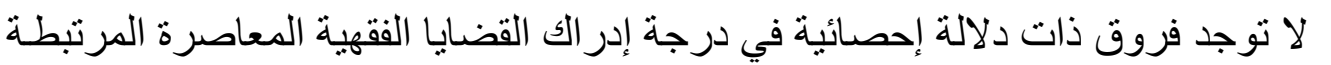

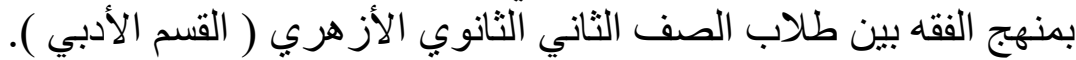

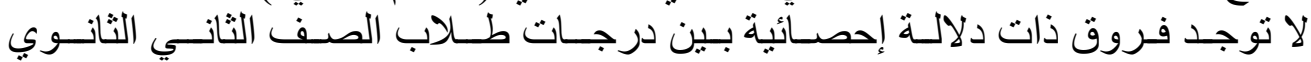

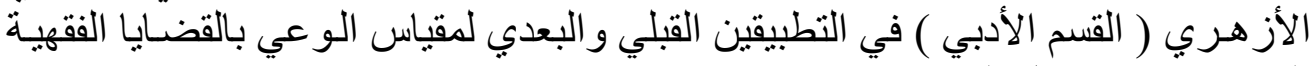
المعاصرة في مجال المعاملات. 


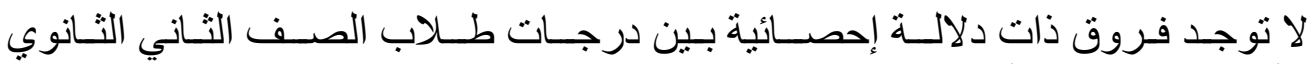

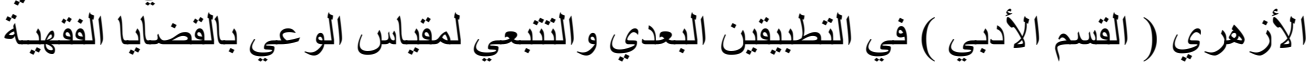
المعاصرة في مجال المعاملات. 5ـ مصطلحسات الدر اســـة:

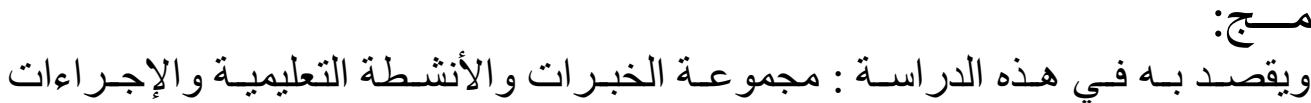

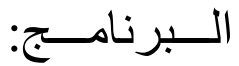

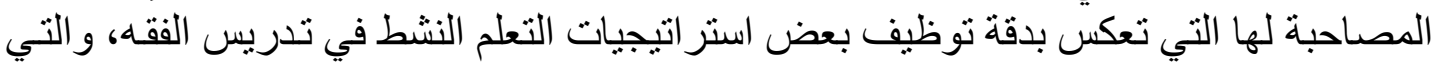

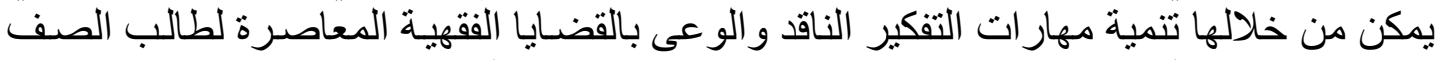

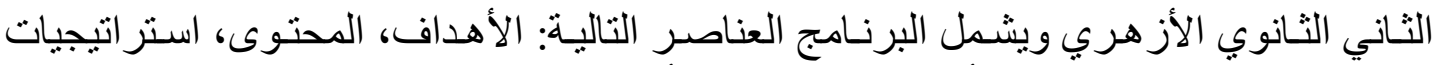

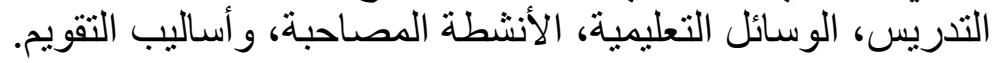

يعرفـه مجهـع اللغـة العربيـة (1973) بأنـهـ في اللغـة: الحفظـ والتقدير و الفهم وسـلامة

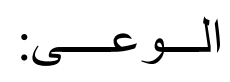

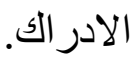

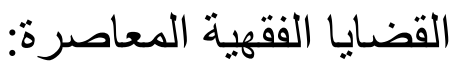

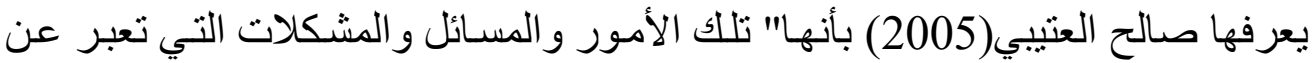

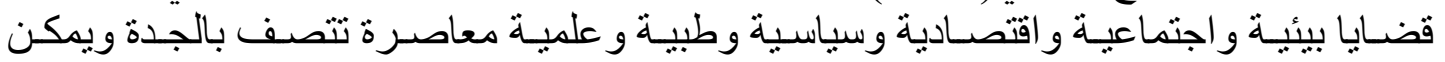

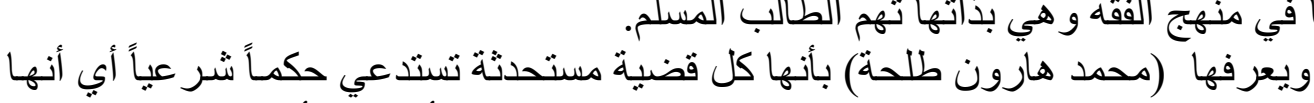
قضية ملحة تحتاج إلى حل شر عي وشامل لكل المن الشكلات التي تطر أ على الأمة الإسلامية.

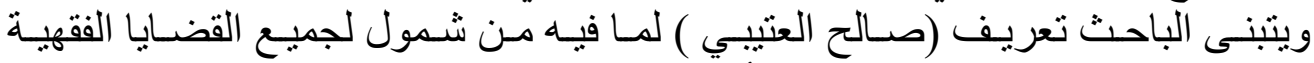

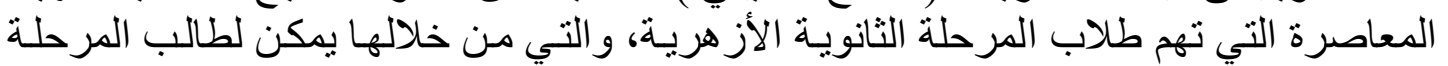
الثانوية تعرف هذه القضايا الفقهية المعاصرة.

الوعى بالقضايا الفقهية المعاصرة:

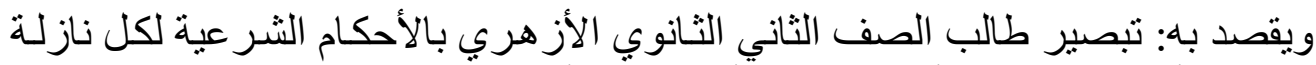

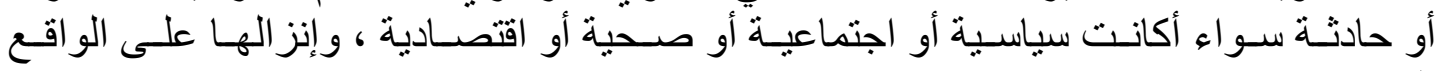

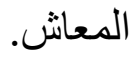

$$
\text { 6- خطــــوات الـــــر اســــة: }
$$

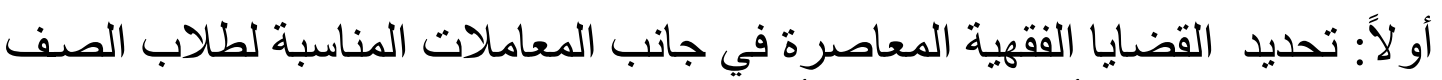

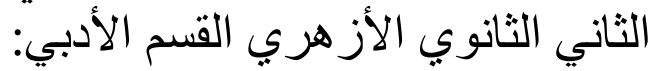

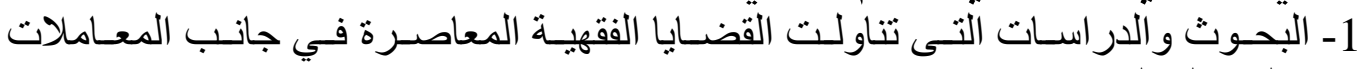

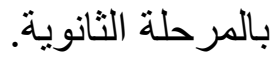
2- خصائص نمو الطلاب في مرحلة المر اهقة. 
برنامج مقتر حلتنريس الققه و أثره على تتمية وعي طلاب

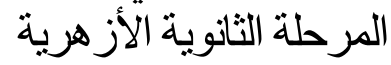

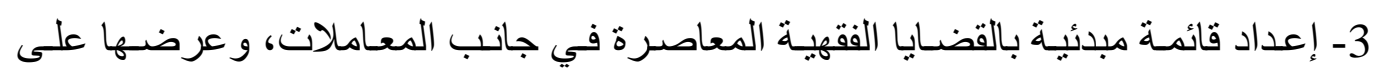

مجمو عة من المحكمين وتعديلها في ضوء آرائرة آئهم.

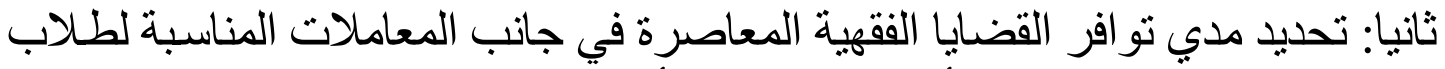

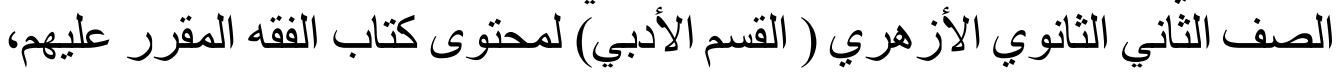

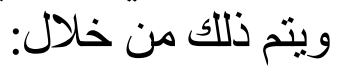

1- تحليل محتوى كتاب الفقه (الاختبار لتعليل المختار) للمذهب الحنفي في ضوء القائمـة السـابق إعدادها.

ثالثاً: بناء البرنامج المقتر ح لتنمية الوعي بالقضايا المعاصرة لطلاب الصف الصف الثاني

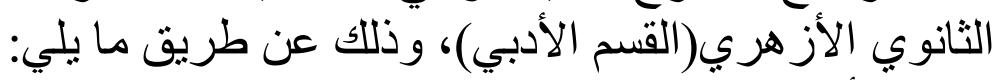

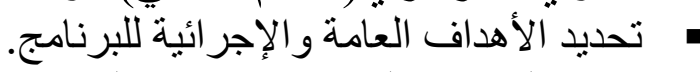

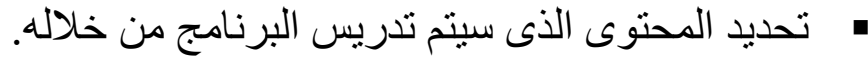

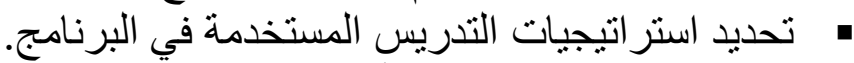
ه تحديد الوسائل التعليمية والأنثطة المناسبة للوعي بالجضايا المعاصرة.

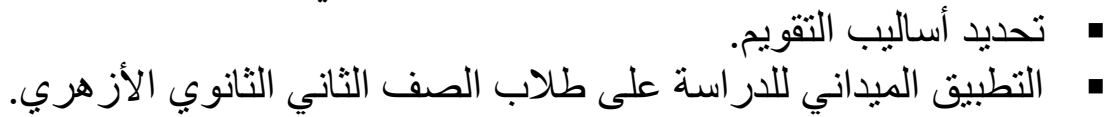

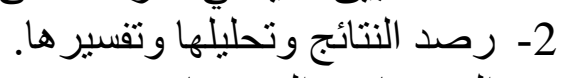
3- 3- التوصيات و المقترحات.

$$
\text { 7ـ أهميــة الــدر اســــــة: }
$$

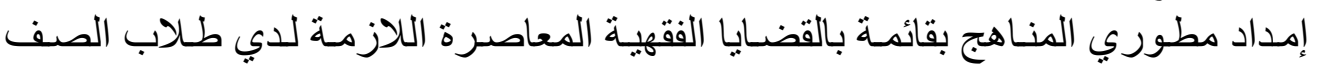

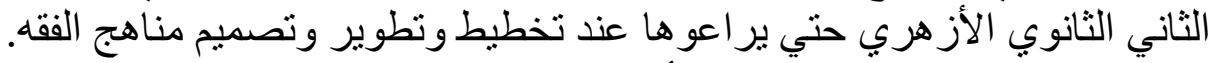

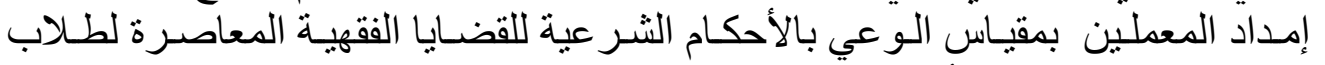

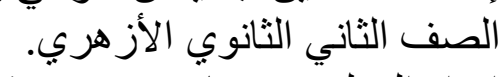

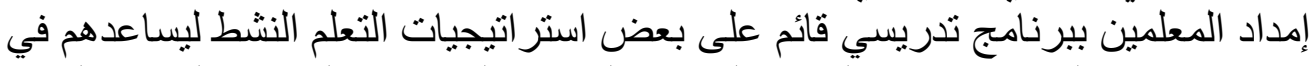

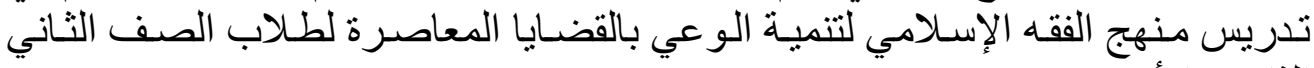

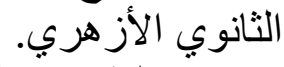

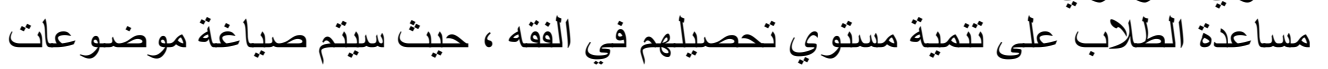
الفقه في ضو ضوء بعض استر اتيجيات التعلم النشط.

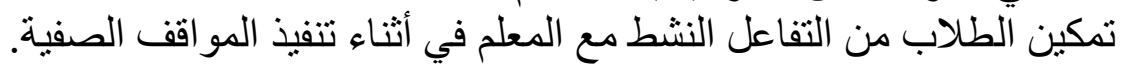

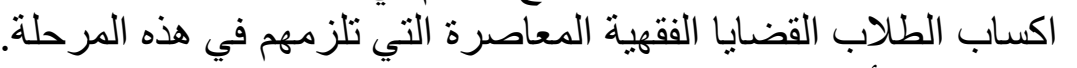

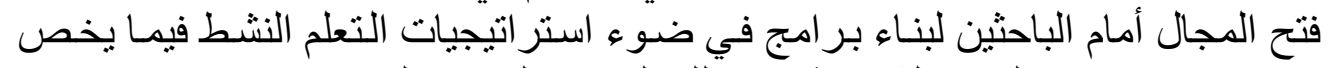

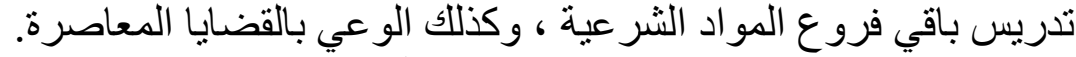

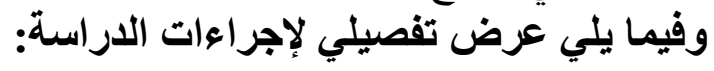


أو لاً: الدر اسـات و البحوث السـابقة التى تناولت القضـايا الفقهيـة المعاصـرة بالمرحلة

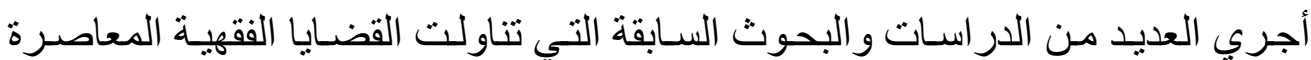

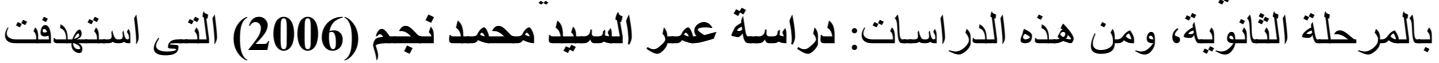

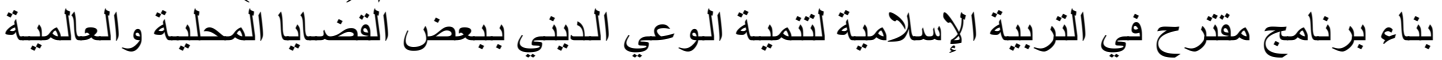

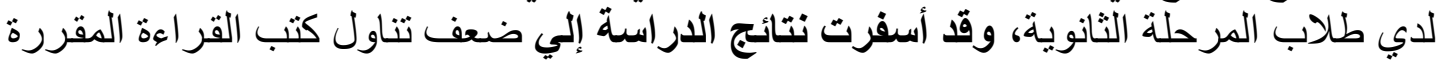

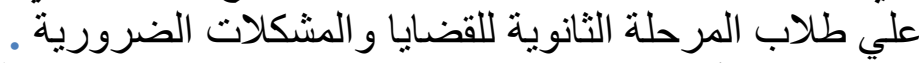

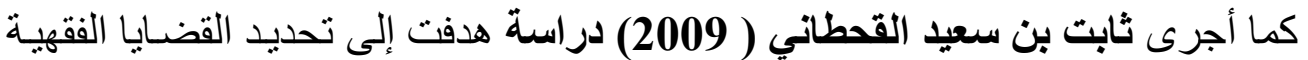

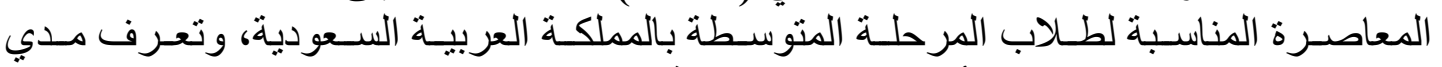

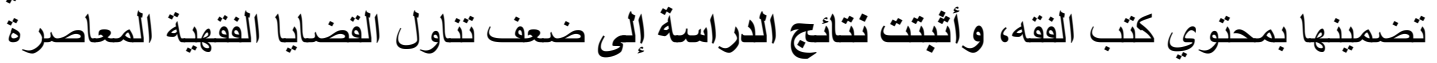

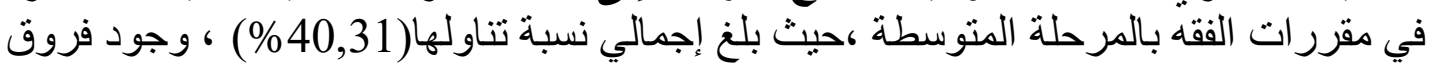

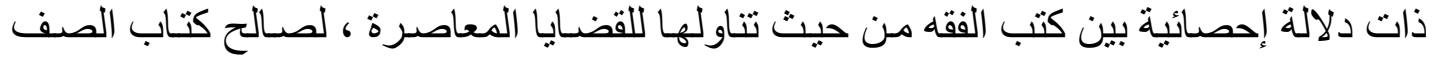

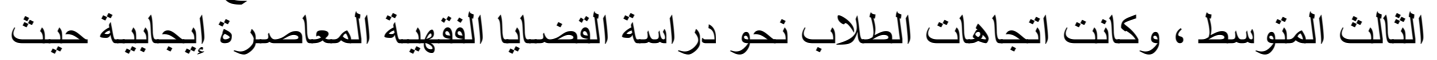

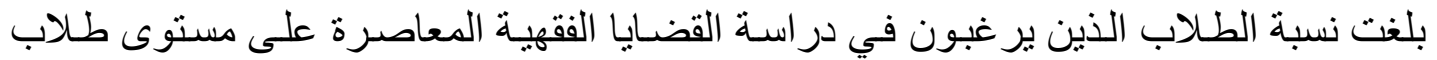

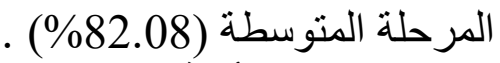

وقامت أمنة بنت محمد المختار الثنقيطي(2009) بلدراسة استهرفت تحديد قضايا فقهـ

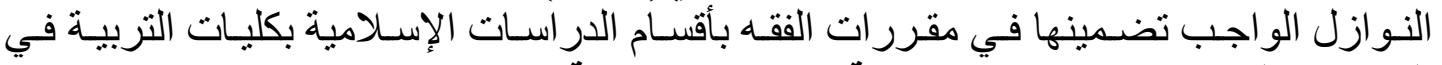

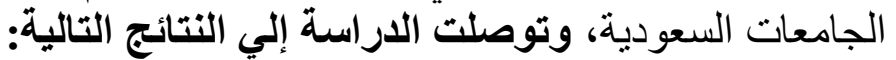

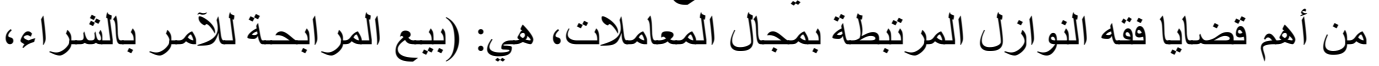

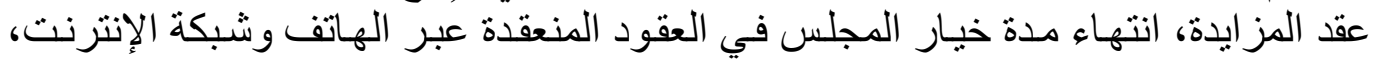

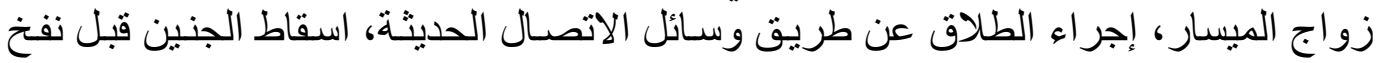
الروح فيه). قلة احتو اء مقرر ات الفقهـ بأقسـام الدر اسـات الإسـلامية لقضـايا فقه النوازل اللازمـة للطـلاب و الطالبات. عدم تلبية مقرر اتل الفقه لاحتياجات الطلاب و الطالبات من حيث معرفة الأحكام الثر عية في

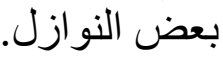

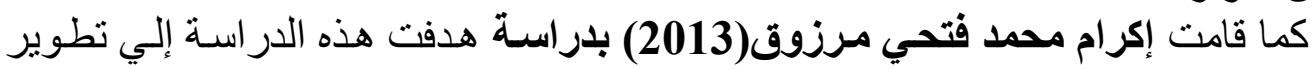

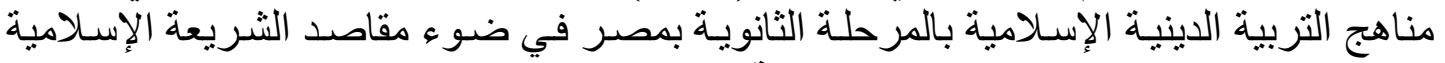
وبعض القضايا المعاصرة، وتوصلت الاراسة إلي وجود فروق ذات دلالة إحصائية عند مستوي

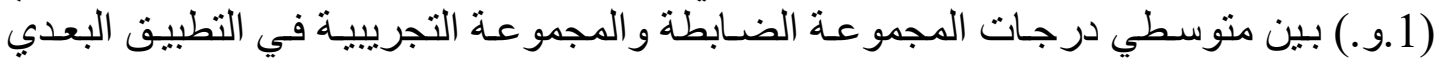

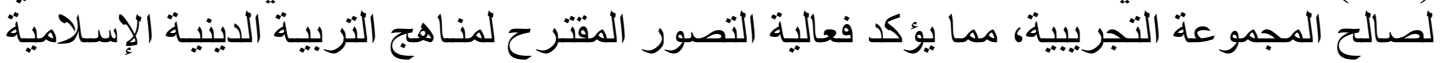

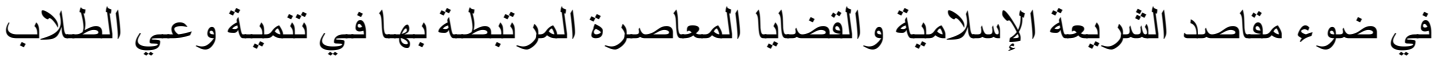
الديني بالأحكام الشر عية وتطبيق تللك المعرفة العلمية في مو اقف الإنس سلوكية حياتية.

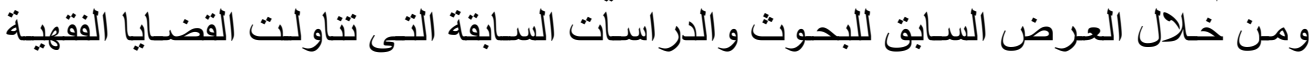

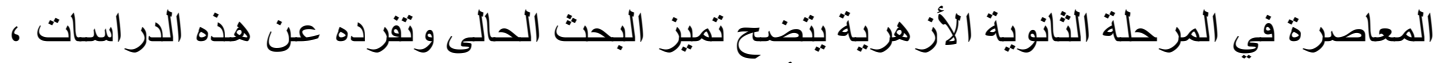

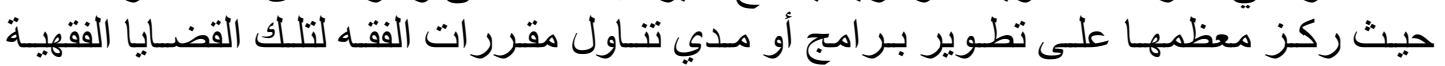

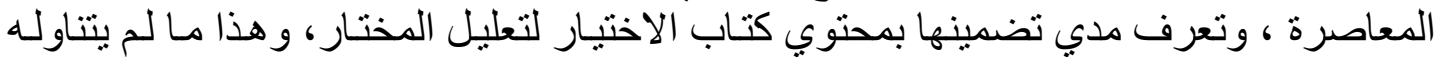
البحوث السعابقة . 
برنامج مقتر حلتنريس الققه و أثره على تتمية وعي طلاب

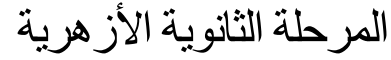

$$
\text { ثانياً: إجراءات الدراسة: }
$$

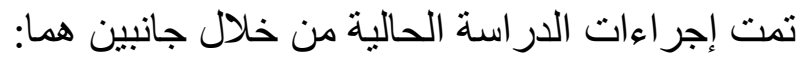

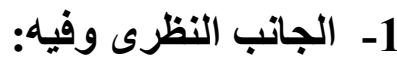

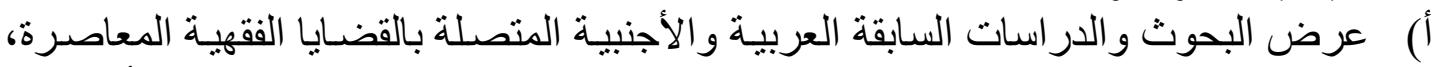

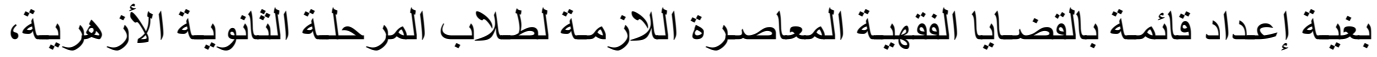

$$
\text { وكذا بناء مقياس الوعي المعرفي لتلك القضائا بالفيا الفقهية المعاصرة. }
$$

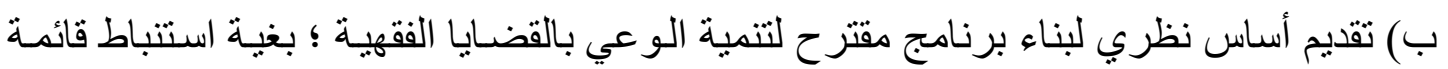

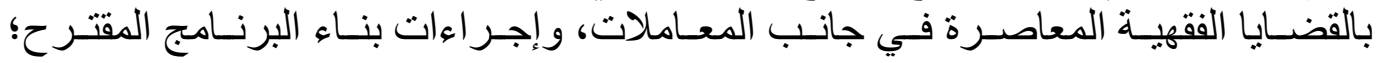

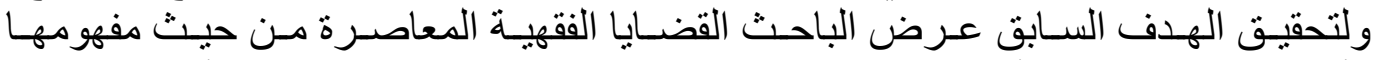

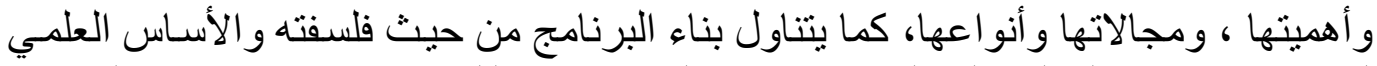

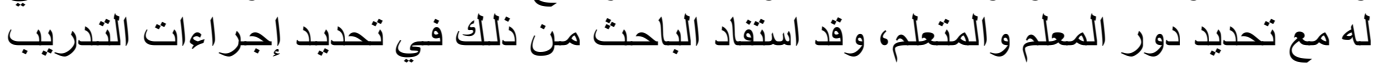
على البرنامج المقتر ح، وإعداد كتاب التلميذ ودليل المعلم.

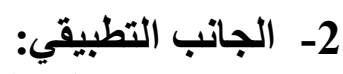

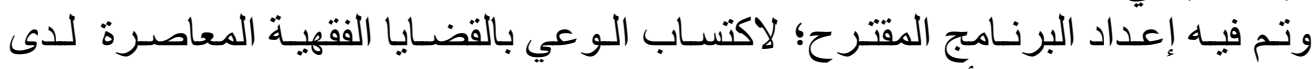

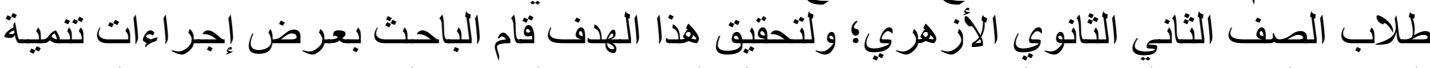

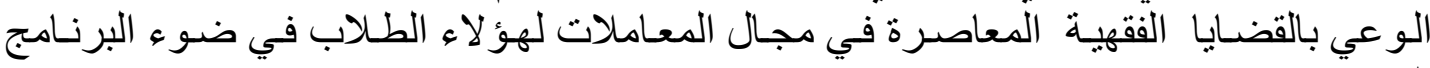

$$
\text { والتي اشتملت على: }
$$

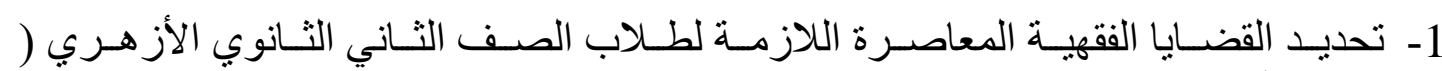

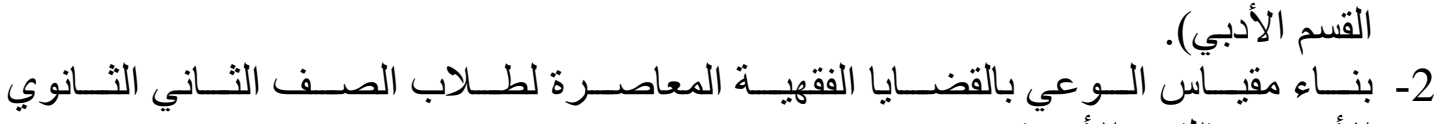
الأز هري (القسم الأدبي).

3- إعداد دليل المعلم لتدريب الطلاب التلاميذ على توظيف الإستر اتيجيات التندريسية المستخدمة

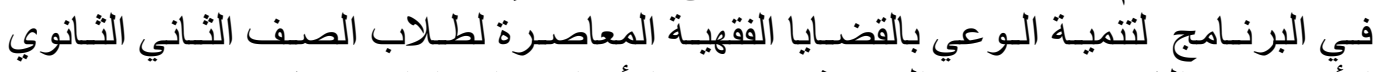

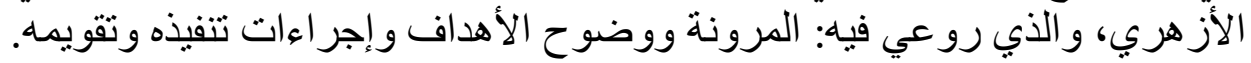
4- إعداد كتاب التلميذ للتدريب على ممارسة إستر اتيجية المنظمات المنتقدة.

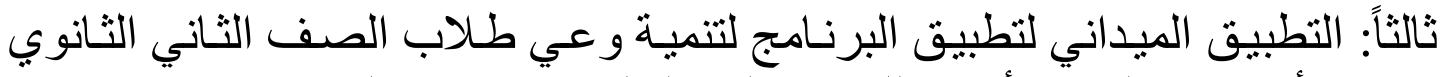

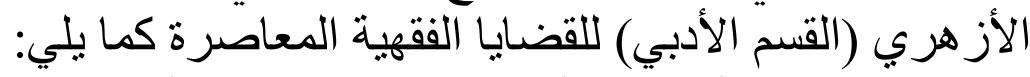

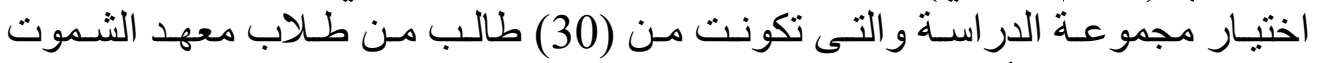

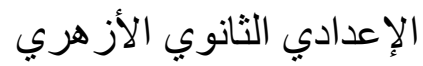

تطبيق مقياس الوعي بالقضايا الفقهية المعاصرة الفقهية قبلياً على مجموعة الدراسة.

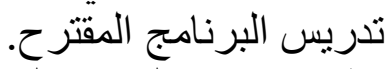
تطبيق مقياس الوعي بالقضايا الفقهية المعاصرة بعدياً. 


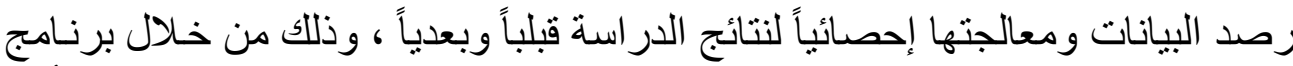

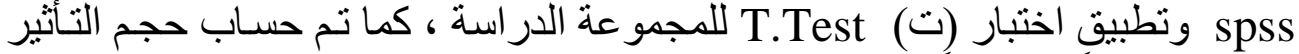

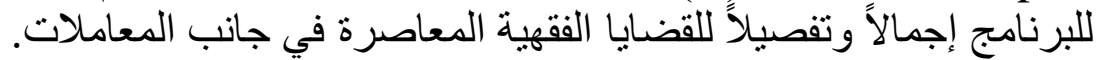

$$
\text { رابعاً: نتائج الدر اسة: }
$$

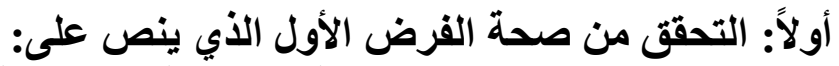

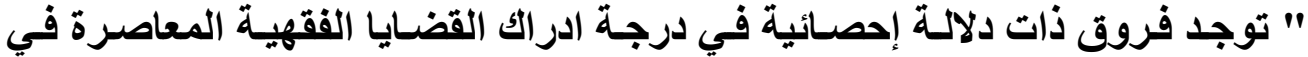

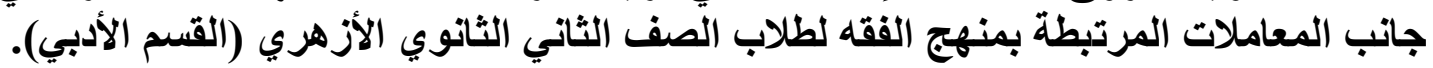

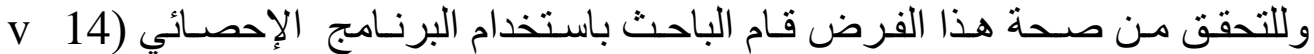

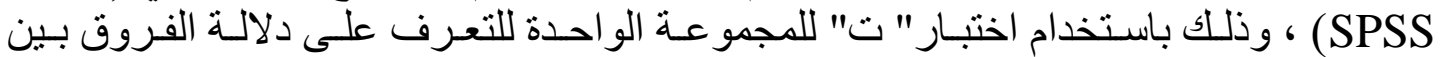

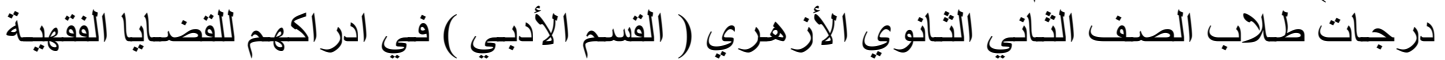

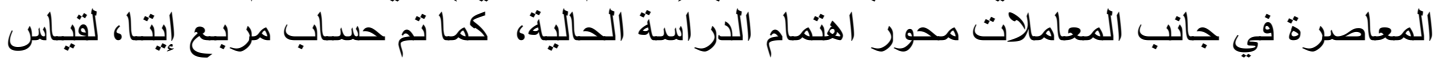

حجم تأثير البرنامج من خلال المعادلة الآتية (فؤاد أبو حطب ، آمال صادق التئ ، 1991، 439) :

$$
\frac{20}{\text { مربع إيتا }}
$$

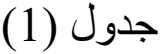

والجدول التالي يوضح ذلك على النحو الآتي:

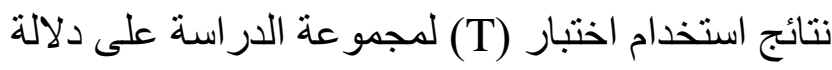

\begin{tabular}{|c|c|c|c|c|c|c|c|c|c|}
\hline الدفسر & مربع & الدلالة & الحرية & قيمة & الالحير اف & الحسابي & العدد & الققهية & 5 \\
\hline$\% 61$ & .61 & .01 & 29 & 6.83 & .96 & 1.20 & 30 & بيع العينة & 1 \\
\hline$\% 64$ & .64 & .01 & 29 & 7.22 & 1.13 & 1.50 & 30 & بيع المرابحة & 2 \\
\hline$\% 59$ & .59 & .01 & 29 & 6.52 & .92 & 1.10 & 30 & بيع التقسيط & 3 \\
\hline$\% 62$ & .62 & .01 & 29 & 6.91 & .73 & .93 & 30 & بيع التورق & 4 \\
\hline$\% 67$ & .67 & .01 & 29 & 7.77 & 91 & 1.30 & 30 & بيع الدّيّن & 5 \\
\hline$\% 63$ & .63 & .01 & 29 & 7.00 & .91 & 1.16 & 30 & الالمنتهي & 6 \\
\hline$\% 80$ & .80 & .01 & 29 & 11.00 & 73 & 1.46 & 30 & المضاربة & 7 \\
\hline$\% 71$ & .71 & .01 & 29 & 8.46 & .66 & 1.03 & 30 & الاستهلاكية & 8 \\
\hline$\% 77$ & .77 & .01 & 29 & 9.90 & 99 & 1.80 & 30 & الودائع & 9 \\
\hline
\end{tabular}

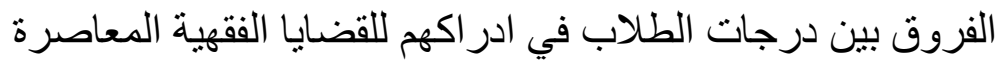


برنامج مقتر حلتنريس الفقه وأثره على تتمية وعي طلاب

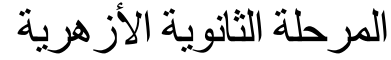

\begin{tabular}{|c|c|c|c|c|c|c|c|c|c|}
\hline & & & & & & & & المصرفية & \\
\hline$\% 77$ & .77 & .01 & 29 & 9.80 & 89 & 1.60 & 30 & البصمة البية & 10 \\
\hline$\% 87$ & .87 & .01 & 29 & 14.23 & .83 & 2.16 & 30 & تحويل الجنس & 11 \\
\hline$\% 82$ & .82 & .01 & 29 & 11.56 & .94 & 2.00 & 30 & الالكثرونية & 12 \\
\hline$\% 78$ & .78 & .01 & 29 & 10.17 & .91 & 1.70 & 30 & الإجهاض & 13 \\
\hline
\end{tabular}

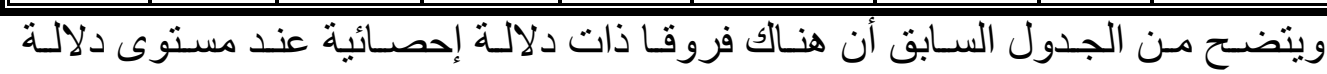

(0.01) بين درجات طلاب الصف الثاني الثانوي الأزهري (القسم الأدبي) في ادر اكهم للقضايا الفقهية المعاصرة في جانب المعاملات.

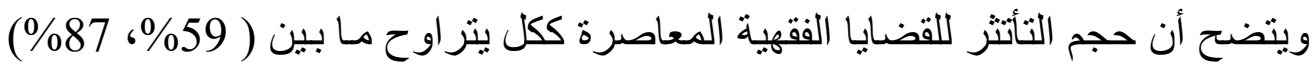
و هذا يدل على أن حجم التأثنير مرتفع جدا.

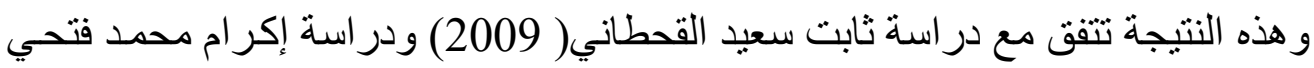
مرزوق(2013)، نايف بن حمد (2014).

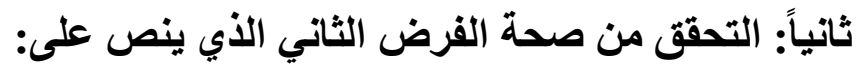

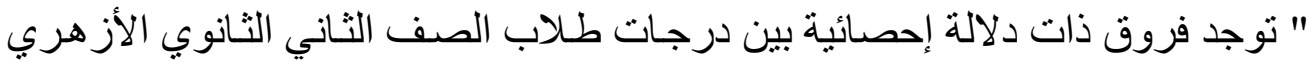
(القسم الأدبي) في التطبيقين القبلي و البعدي لمقياس الوعي المعرفي للقضايا الفقهية المعاصرة

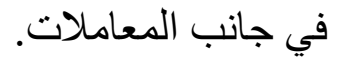
v 14) وللتحقق من صحة هذا الفرض قام الباحث باستخدام البرنـامج الإحصـائي

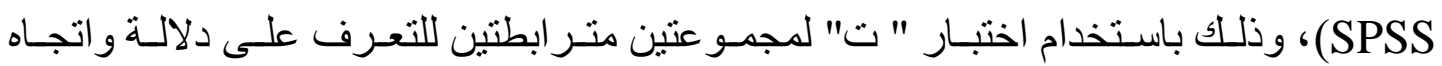

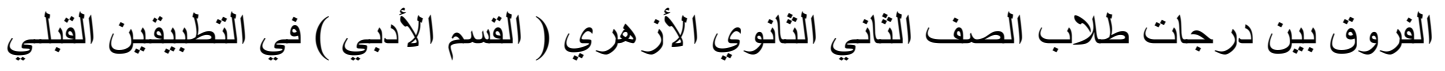

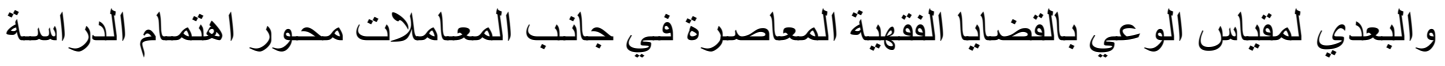

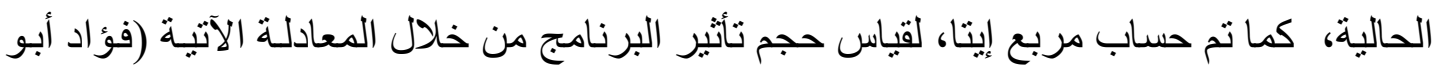
حطب ، آمال صادق ، 1991، 1939 4) :

مربع إيتا




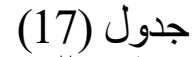

و الجدول التالي يوضح ذلك على النحو الآتي:

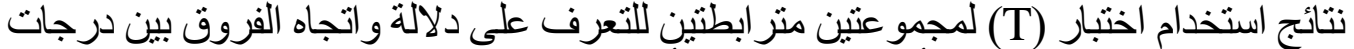

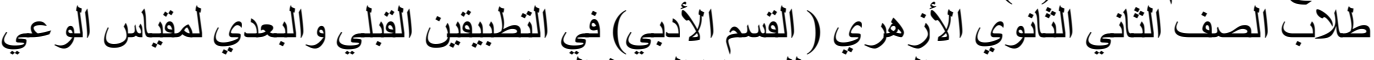

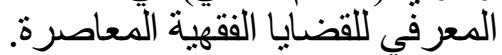

\begin{tabular}{|c|c|c|c|c|c|c|c|c|c|c|}
\hline الكفنر & رايتا & مستوي & قتيمة & الررجية & المعياري & المتوسط & التطبيق & العدد & الفقضية & 5 \\
\hline \multirow[t]{2}{*}{$\% 62$} & \multirow[t]{2}{*}{.62 } & \multirow[t]{2}{*}{0.01} & \multirow{2}{*}{6.91} & \multirow[t]{2}{*}{29} & .96 & 1.20 & القبلي & \multirow[b]{2}{*}{30} & \multirow{2}{*}{ بيع العينة } & \multirow{2}{*}{1} \\
\hline & & & & & .49 & 2.63 & البعدي & & & \\
\hline \multirow[t]{2}{*}{$\% 28$} & \multirow[t]{2}{*}{.28} & \multirow{2}{*}{0.01} & \multirow{2}{*}{3.40} & \multirow[t]{2}{*}{29} & 1.14 & 1.50 & القبلي & \multirow{2}{*}{30} & \multirow{2}{*}{ المرّبحِحة } & \multirow{2}{*}{2} \\
\hline & & & & & .61 & 2.33 & البعدي & & & \\
\hline \multirow{2}{*}{$\% 52$} & \multirow{2}{*}{.52} & \multirow{2}{*}{0.01} & \multirow{2}{*}{5.61} & \multirow{2}{*}{29} & .92 & 1.10 & القبلي & \multirow{2}{*}{30} & \multirow{2}{*}{ بيع التقسيط } & \multirow{2}{*}{3} \\
\hline & & & & & .62 & 2.23 & البعدي & & & \\
\hline \multirow{2}{*}{$\% 77$} & \multirow{2}{*}{. 77} & 0.01 & \multirow{2}{*}{10.05} & \multirow{2}{*}{29} & .74 & .93 & القبلي & \multirow{2}{*}{30} & \multirow{2}{*}{ بيع التورق } & 4 \\
\hline & & & & & $\frac{.50}{91}$ & $\frac{2.56}{130}$ & البعدي & & & \\
\hline$\% 58$ & .58 & 0.01 & 6.29 & 29 & $\frac{.91}{50}$ & $\frac{1.50}{2.53}$ & التعدي & 30 & بيع الدّين & 5 \\
\hline & & & & & .91 & 1.16 & القبلي & & الإجارة & \\
\hline$\% 67$ & .67 & 0.01 & 7.70 & 29 & .50 & 2.43 & البعدي & 30 & بالتملنتئت & 6 \\
\hline $0 / 49$ & 49 & 001 & 487 & 29 & .73 & 1.46 & القبلي & 30 & المضار بـة & 7 \\
\hline & & & & & .66 & 2.33 & البعدي & & & 7 \\
\hline$\% 79$ & 79 & 0.01 & 10.52 & 29 & .67 & 1.03 & القبلي & 30 & القروض & 8 \\
\hline 8013 & .13 & 0.01 & 10.52 & & .48 & 2.66 & البعدي & J0 & الاستهلاكية & 0 \\
\hline$\% 19$ & 19 & 001 & 263 & 29 & .99 & 1.80 & القبلي & 30 & الودائع & 0 \\
\hline & & & $2.0 \mathrm{~s}$ & & .56 & 2.40 & البعدي & 30 & المصرفية & 7 \\
\hline$\% 39$ & 39 & 001 & 432 & 29 & .89 & 1.60 & القبلي & 30 & البصمة & 10 \\
\hline 7059 & .39 & 0.01 & 4.52 & 29 & .55 & 2.36 & البعدي & 50 & الوراثية & 10 \\
\hline 024 & 21 & غير & 130 & 29 & .83 & 2.16 & القبلي & 30 & تحويل & 11 \\
\hline & & & & & .67 & 2.43 & البعدي & & & \\
\hline$\% 72$ & 072 & غير & 1.50 & 29 & .94 & 2.00 & القبلي & 30 & التجارة & 12 \\
\hline & & دالة & & & .71 & 2.33 & البعدي & & الالكترونية & 12 \\
\hline$\% 28$ & 28 & 0.01 & 3.34 & 29 & .91 & 1.70 & القبلي & 30 & الاحماض & 13 \\
\hline & & & & & .67 & 2.36 & البعدي & & & \\
\hline
\end{tabular}

ويتضح من الجدول السابق الآتي:

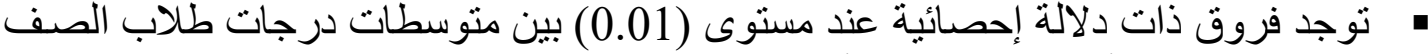

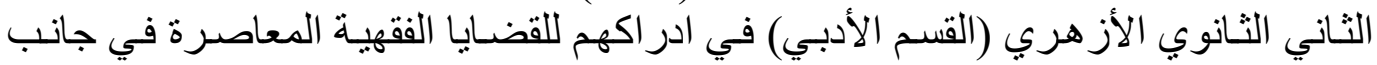

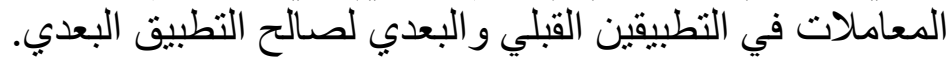
لا توجد فروق ذات دلالة إحصائية بين متوسطي الفيات درجات الطّلاب في ادر اكهم للقضيتين

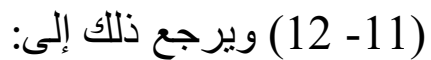
• أن مستوي عقل الطلاب في هذه المرحلة لا يتجاوز التنـاول إلا بالقضايا الثـائعة في

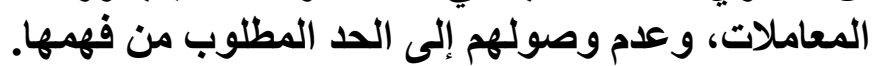


برنامج مقتر حلتدريس الفقه و أتزه على تتمية وعي طلاب

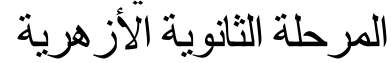

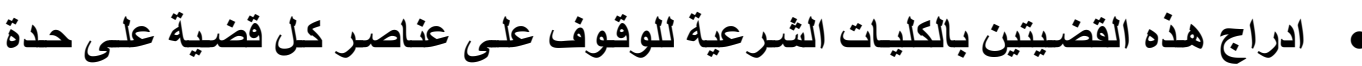

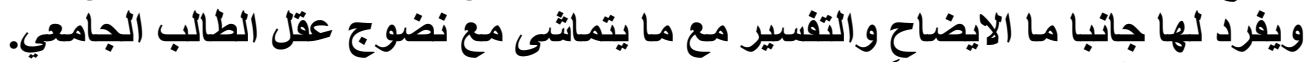

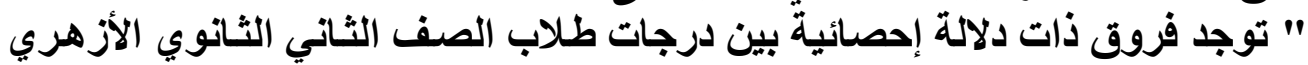

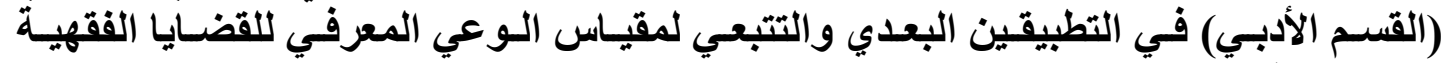
المعاصرة في جانب المعاملات.

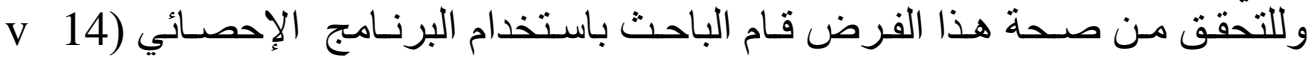

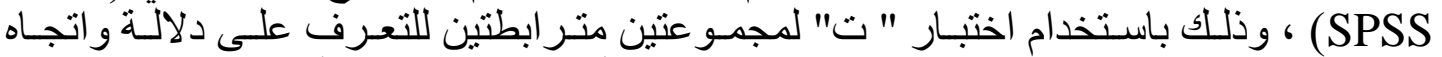

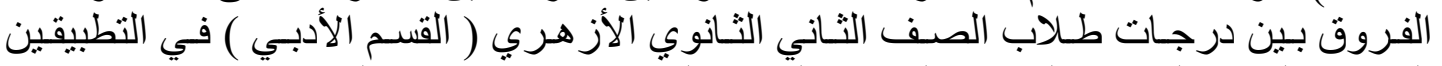

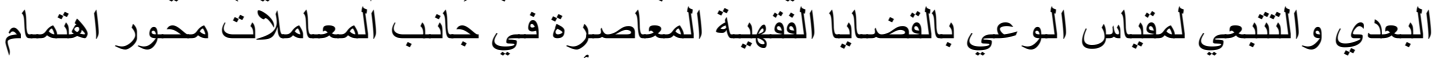

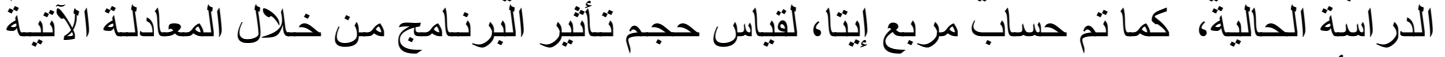

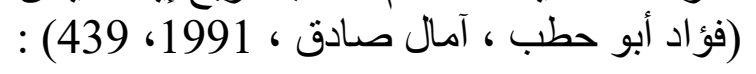

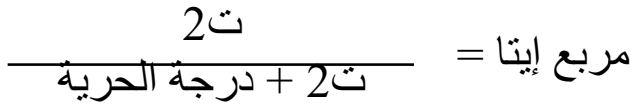

$$
\begin{aligned}
& \text { جدول (19) } \\
& \text { والجدول التالي يوضح ذلك على النحو الآتي: }
\end{aligned}
$$

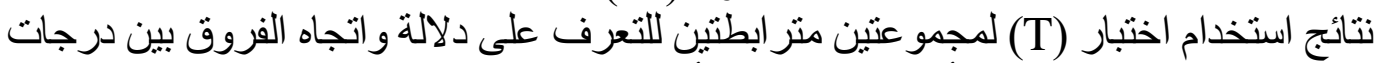

\begin{tabular}{|c|c|c|c|c|c|c|c|c|c|c|}
\hline المفسر & التأثنير & الدلالة & قيمة & الحرية & الانحعراف افي & المتوسط & التطبيق & العدد & الققيةية & r \\
\hline \multirow{2}{*}{$\% 23.3$} & \multirow{2}{*}{0.233} & \multirow{2}{*}{0.01} & \multirow{2}{*}{2.97} & \multirow{2}{*}{29} & .49 & 2.63 & البعدي & \multirow[b]{2}{*}{30} & \multirow{2}{*}{ بيع العينة } & \multirow{2}{*}{1} \\
\hline & & & & & .34 & 2.86 & التتبعي & & & \\
\hline \multirow{2}{*}{$\% 11.91$} & \multirow{2}{*}{.119} & \multirow{2}{*}{0.01} & \multirow{2}{*}{1.98} & \multirow{2}{*}{29} & .61 & 2.33 & البعدي & \multirow{2}{*}{30} & \multirow{2}{*}{ المرابحة } & \multirow{2}{*}{2} \\
\hline & & & & & .50 & 2.50 & التتبعي & & & \\
\hline \multirow{2}{*}{$\% 26$} & \multirow{2}{*}{.26} & \multirow{2}{*}{0.01} & \multirow{2}{*}{3.24} & \multirow{2}{*}{29} & .62 & 2.23 & البعدي & \multirow{2}{*}{30} & \multirow{2}{*}{ بيع التقسيط } & \multirow{2}{*}{3} \\
\hline & & & & & .50 & 2.50 & التتبعي & & & \\
\hline \multirow{2}{*}{$\% 3.30$} & \multirow{2}{*}{.33} & \multirow{2}{*}{0.01} & \multirow{2}{*}{1.00} & \multirow{2}{*}{29} & .50 & 2.56 & البعدي & \multirow{2}{*}{30} & \multirow{2}{*}{ بيع التورق } & \multirow{2}{*}{4} \\
\hline & & & & & .49 & 2.60 & التتبعي & & & \\
\hline \multirow{2}{*}{$\% 3.30$} & \multirow{2}{*}{.33} & \multirow{2}{*}{0.01} & \multirow{2}{*}{1.00} & 20 & .50 & 2.53 & البعدي & 30 & بـ الدّّن & 5 \\
\hline & & & & 29 & .50 & 2.56 & التتبحي & 30 & بيع ندين & $J$ \\
\hline or 332 & 33 & 001 & 100 & 20 & .50 & 2.43 & البعدي & 30 & الإلجارة & 6 \\
\hline 403.30 & & 0.01 & 1.00 & 29 & .50 & 2.46 & التتبعي & 30 & بالتملئق & 0 \\
\hline$\% 925$ & 925 & 001 & 172 & 29 & .66 & 2.33 & البعدي & 30 & المضLار تة & 7 \\
\hline & & & & & .50 & 2.50 & التتبعي & & & \\
\hline$\% 1.10$ & .110 & 0.01 & .57 & 29 & .48 & 2.66 & البعدي & 30 & القروض & 8 \\
\hline
\end{tabular}

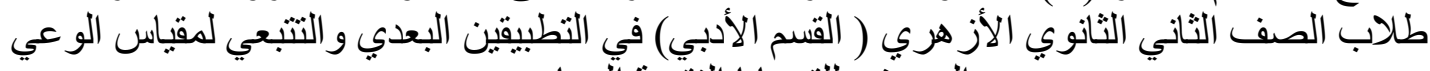
المعرفي للقضايا الفقهية آلمعاصرة. 


\begin{tabular}{|c|c|c|c|c|c|c|c|c|c|c|}
\hline & & & & & .48 & 2.66 & النتبعي & & الاستهلاكية & \\
\hline \multirow{2}{*}{$\% 9.94$} & \multirow{2}{*}{.994} & \multirow{2}{*}{0.01} & \multirow{2}{*}{1.79} & \multirow{2}{*}{29} & .56 & 2.40 & البعدي & \multirow{2}{*}{30} & الو دائع & \multirow{2}{*}{9} \\
\hline & & & & & .50 & 2.43 & التتبعي & & المصرفية & \\
\hline \multirow{2}{*}{$\% 11.91$} & \multirow{2}{*}{.119} & \multirow{2}{*}{0.01} & \multirow{2}{*}{1.98} & \multirow{2}{*}{29} & .55 & 2.36 & البعدي & \multirow{2}{*}{30} & البصمة & \multirow{2}{*}{10} \\
\hline & & & & & .50 & 2.46 & التنبعي & & الور اثية & \\
\hline \multirow{2}{*}{$\% 16.5$} & \multirow{2}{*}{.165} & \multirow{2}{*}{0.01} & \multirow{2}{*}{2.40} & \multirow{2}{*}{29} & .67 & 2.43 & البعدي & \multirow{2}{*}{30} & تحويل & \multirow{2}{*}{11} \\
\hline & & & & & .49 & 2.60 & التتبعي & & & \\
\hline \multirow{2}{*}{$\% 27$} & \multirow{2}{*}{.27} & \multirow{2}{*}{0.01} & \multirow{2}{*}{3.34} & \multirow{2}{*}{29} & .71 & 2.33 & البعدي & \multirow{2}{*}{30} & التجارة & \multirow{2}{*}{12} \\
\hline & & & & & .50 & 2.50 & النتبعي & & الالكترونية & \\
\hline \multirow{2}{*}{$\% 27$} & \multirow{2}{*}{.27} & \multirow{2}{*}{0.01} & \multirow{2}{*}{3.34} & \multirow{2}{*}{29} & .67 & 2.36 & البعدي & \multirow{2}{*}{30} & \multirow{2}{*}{ الإجهاض } & \multirow{2}{*}{13} \\
\hline & & & & & .46 & 2.70 & التتبعي & & & \\
\hline
\end{tabular}

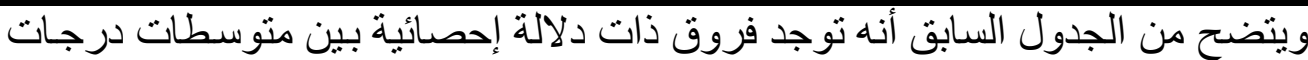

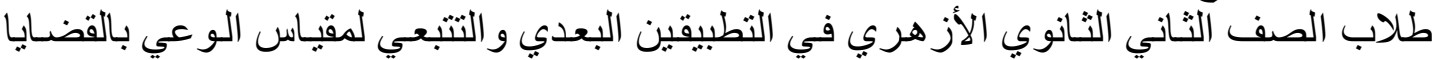

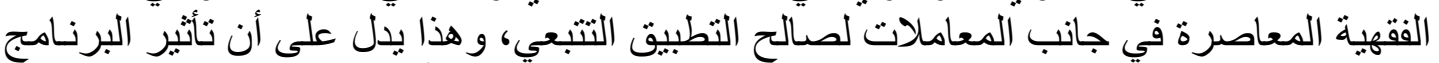

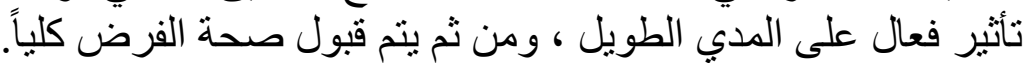

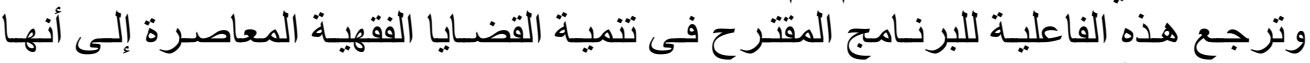
راعى عند تطبيقه الأمور الآتية:

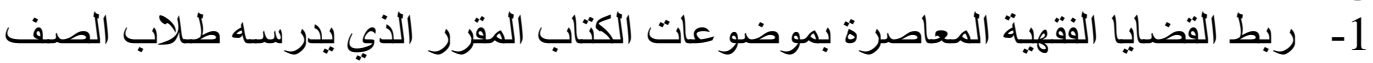

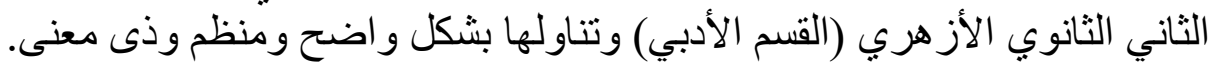

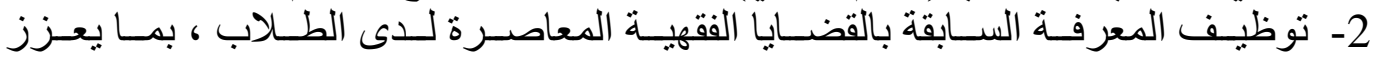
اكتسابهم لها.

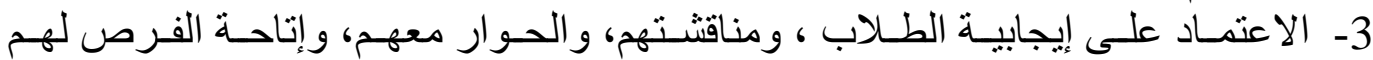
للمشاركة بحرية فى التكليفات و الأنشطة و التندريبات.

\section{توصلت الار اسة إلى النتائج الآتية:}

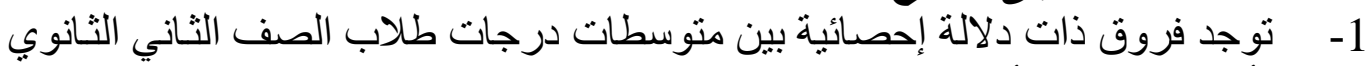

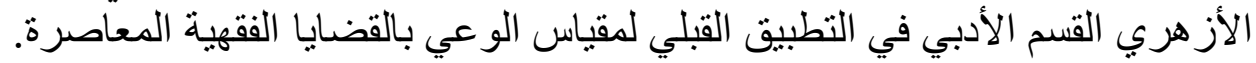

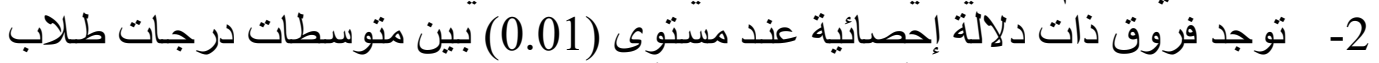

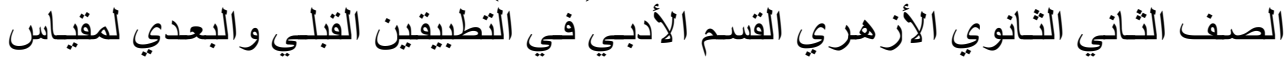

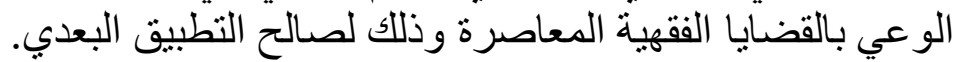

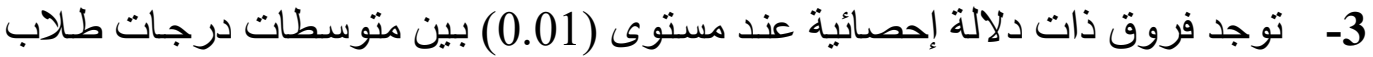

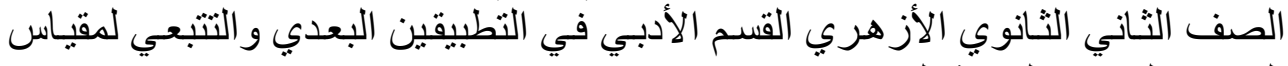
الوعي بالقضايا الفقهية المعاصرة. حادي عثر : توصيات الدر اسة ومقترحاتها:

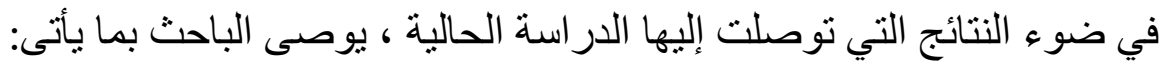

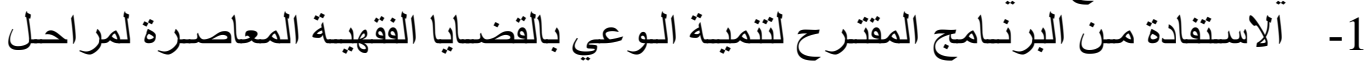
التعليم العلبا في الأزهر الثريف. الثران. 2- ضرورة تركيز الطلاب على تعلم الأحكام الثر عية وكيفية استخر اجها لكل قضية فقهية معاصرة و إنو الها على الو اقع المعاش. 
برنامج مقتر حلتنريس الققه و أثره على تتمية وعي طلاب

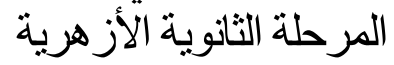

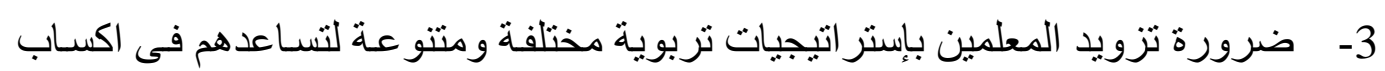

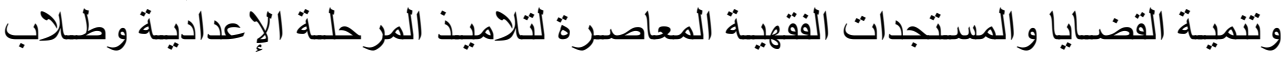

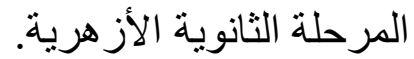

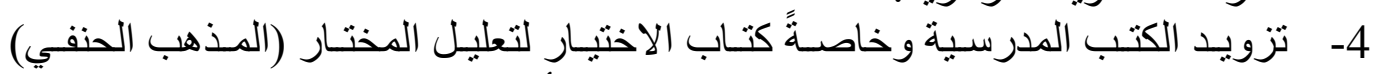
ببعض القضايا التي تهم طالب المرحلة الثانوية الأز هرية.

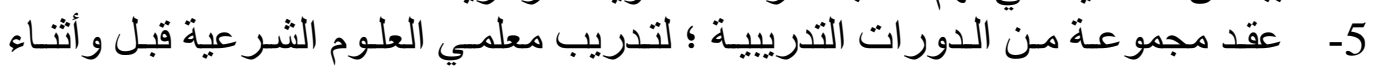

الخدمة على إستر اتيجيات التعلم الحديثة والتعرف على على بنـاء البر امج التندريسية القائمـة عليها.

في ضوء نتائج الدارسة وتوصياتها ، يقترح الباحث بعض الاراسات التي ربما تصلح كلر اسات مستقبلية وتتمثل في:

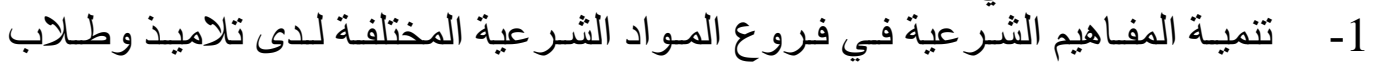
المر احل النعليمية المختلفة.

2 - 2 - فاعلية استخدام الإستر اتيجيات الحديثة في تنمية القضايا الفقهية المعاصرة.

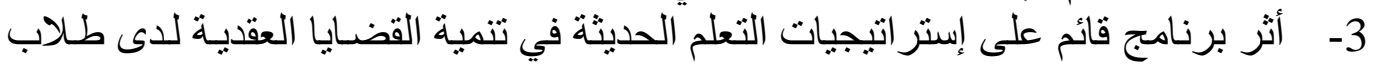
المر احل التعليمية العليا ( الثانوية ـ البئية الجامعية).

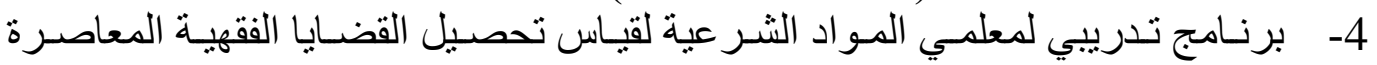
باستخدام إستر اتيجية التعلم النشط. 


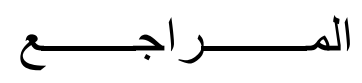

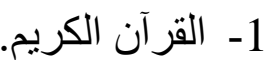

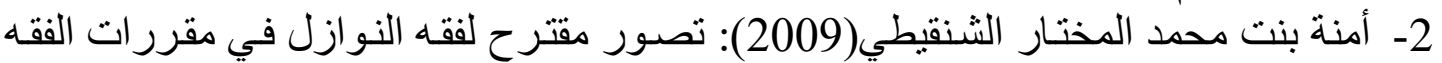

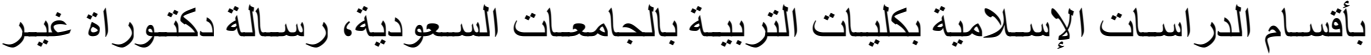
منشورة، كلية التربية ، جامعة طيبة، المدينة المنورة، المملكة العربية السعودية.

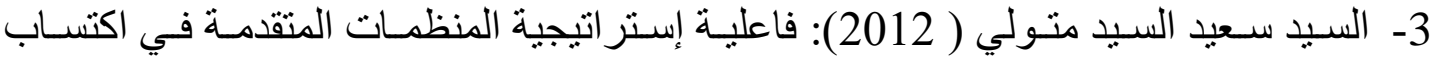

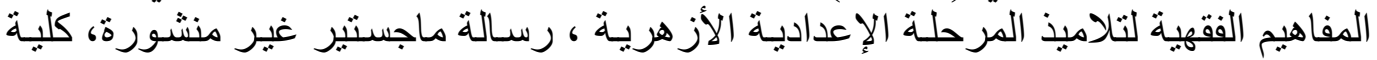

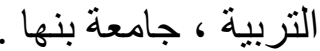

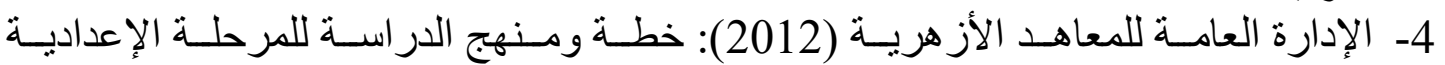

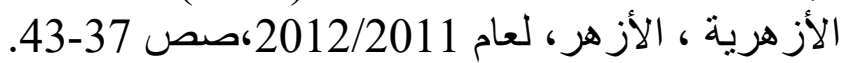

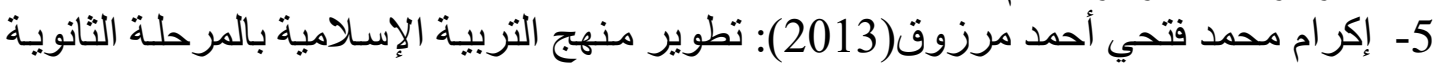

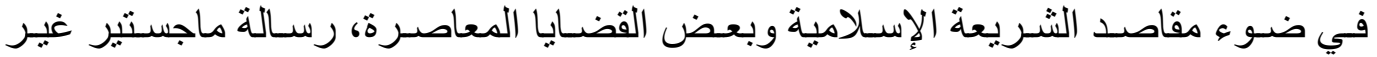

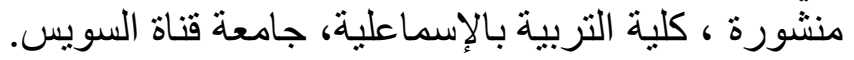

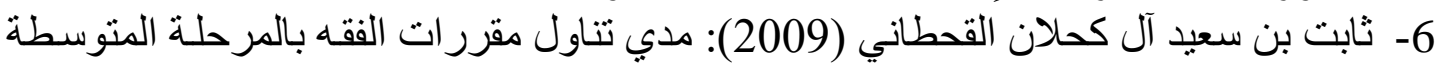

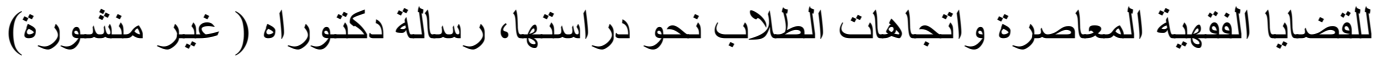
، كلية التربية، جامعة أم القري، المعاية المملكة العربية السعودية.

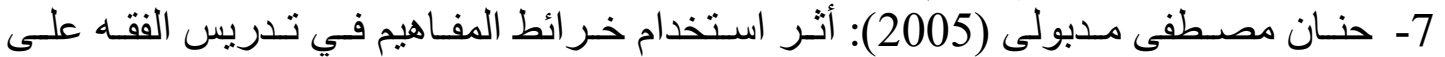

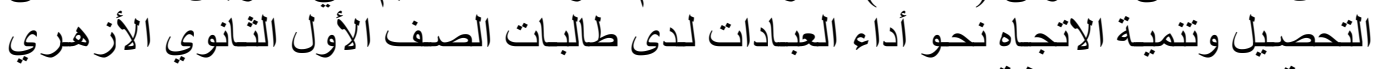

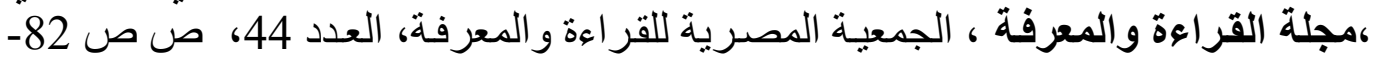

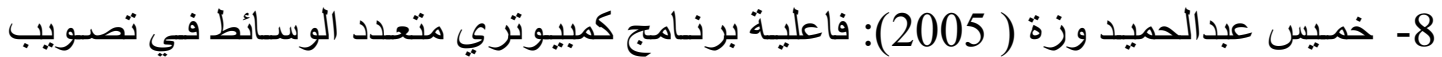

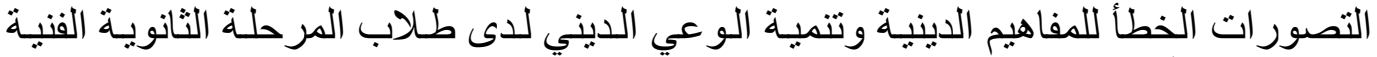

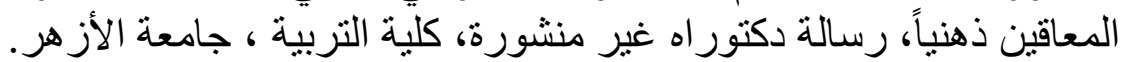

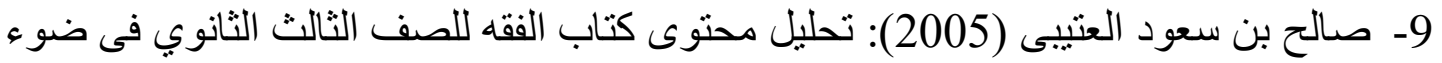

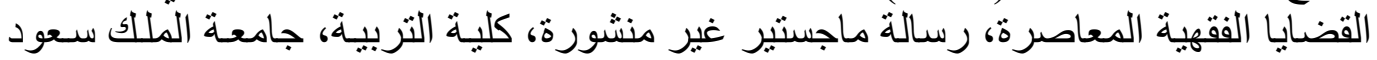
، المملكة العربية السعودية. 10- عـاطف رضـوان عبدالله (1994): تقويم كتاب الفقه في المرحلـة الإعداديـة الأزهريـة، رسالة ماجستير "غير منشورة " ،كلية التربية ، جامعة الزقازيت.

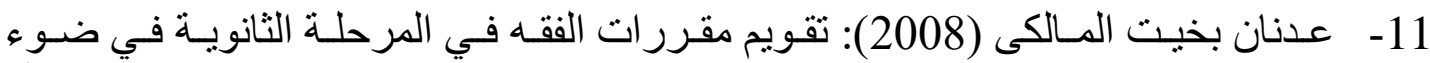

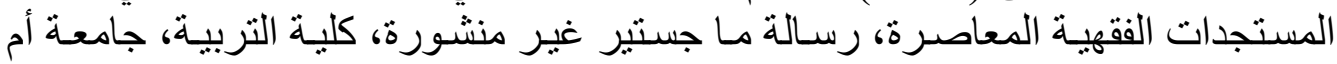
القرى، المملكة العربية السعودية.

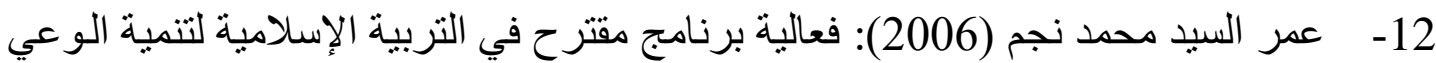

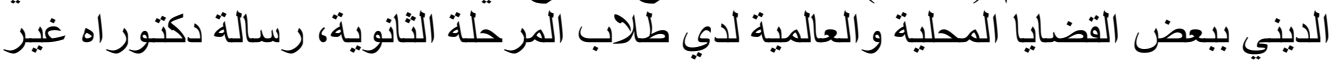

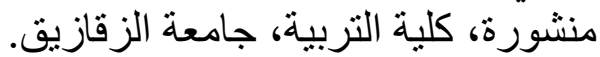

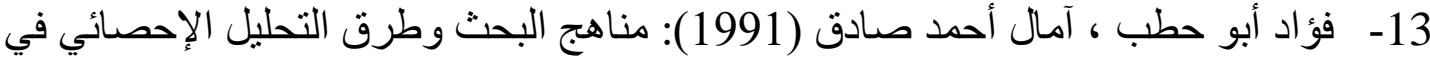

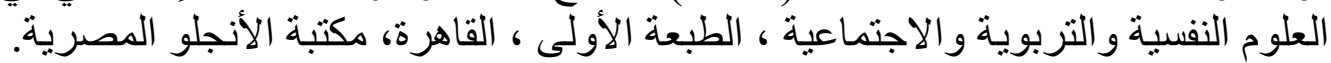

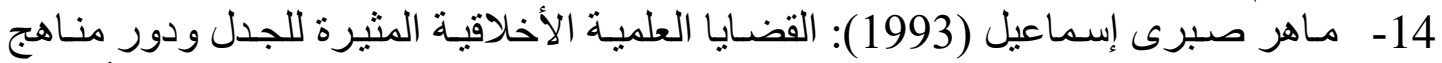

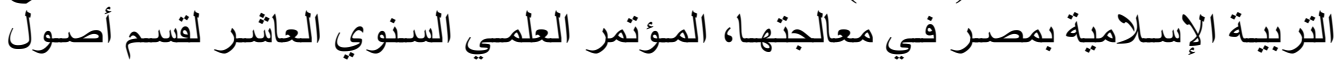


برنامج مقترح لتنديس الفقه و أتزه على تتمية وعي طلاب

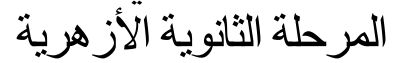

التربية، كلبة التربية، جامعة المنصورة،" التربية الدينية وبناء الإنسان المصرى ،المجلدا

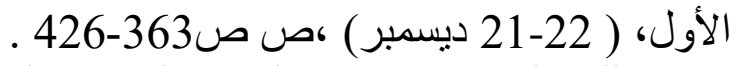

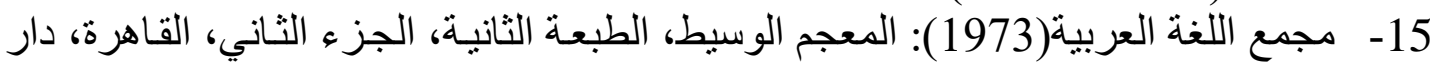

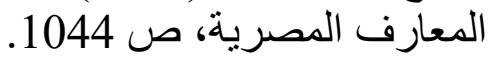

16- محد بن فهر البشر(2006): أثر استخدام خر ائط الدفاهيم فى التحصيل الدراسى وتلتميـة

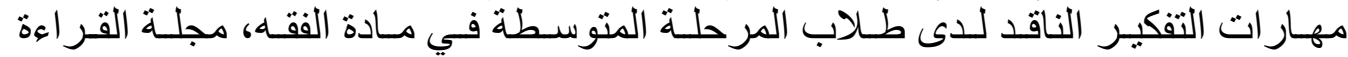

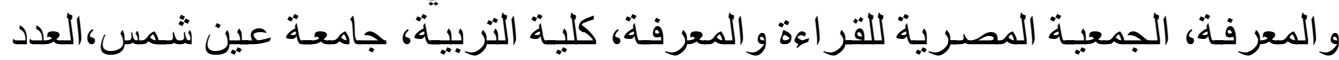

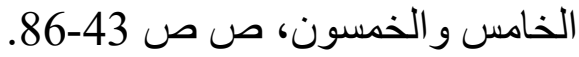

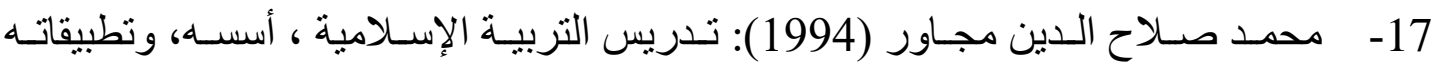

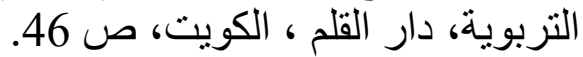

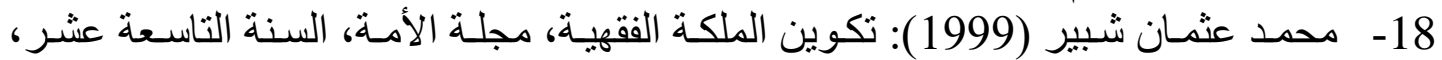

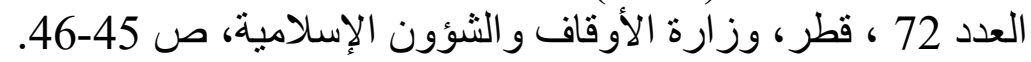

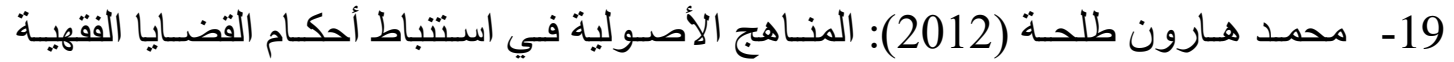

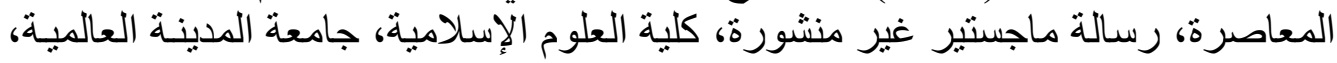

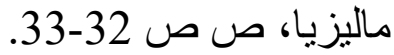

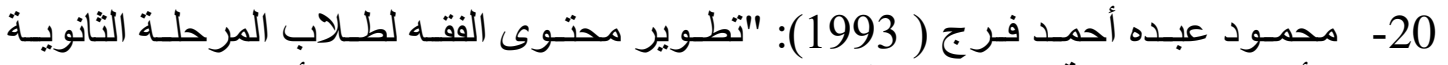

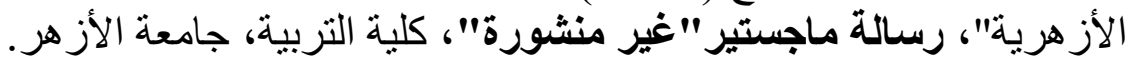

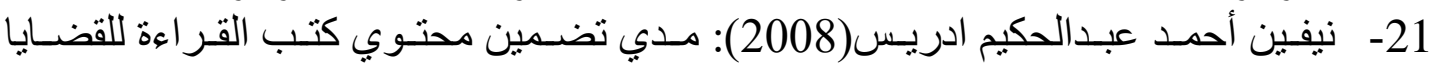

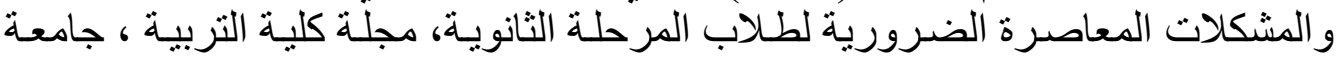

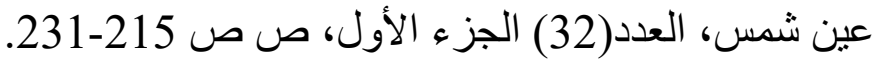

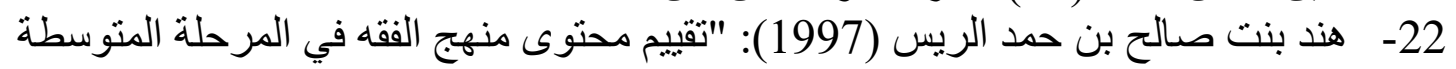

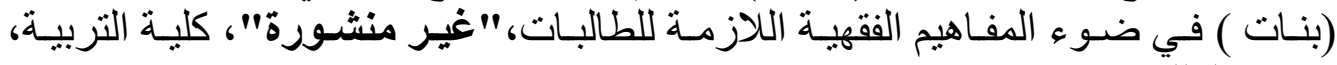
جامعة الملك سعود. 23- يونس محمد فارس الموسى (2001): درجة اكتساب طلبة الصفوف (السبابع ،و الثامن،

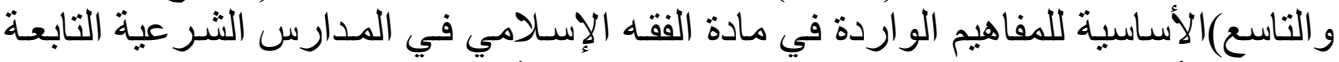

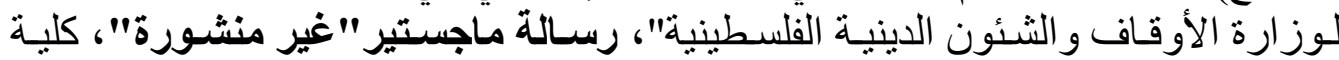
الدراسات العليا ، جامعة النجاح الوطنية. 


\section{Ahstract}

This Research aimed at Finding out the Effectiveness of the Suggested Program in Teaching Fiqah and its Effect on Developing the Awareness of the AZAHAR Secendary School Student.for the Contem porary issues.

To achieve this gool. The researcher Made ateaching program. Its Elements are The Aims. The content, Method bgy the Accompanied Actives and Evaluation to Devebpe same Contemoporary. ISS ues whichRepresent in ( Oncredit, Falling preganey, Treaing profit Selling. Changing sex,and DNA). the Sample f the Study, Contains (30) Student of EL AZAHAR Secondary School Students. The result of the Study come to the Effectiveness of the Suggested program in Teaching Fiqah and its Effect on Developing the Awareness of The Student of The Sample of Study. 